\title{
Sınıf Öğretmenlerinin Alternatif Ölçme ve Değerlendirme Hakkındaki Görüşlerinin Belirlenmesi*
}

\author{
Mehmet ÖZENÇ ${ }^{1}$, Cihangir DOĞAN ${ }^{2}$, Mustafa ÇAKIR ${ }^{3}$ \\ ${ }^{1}$ Dr,MEB, mozenc38@,hotmail.com \\ ${ }^{2}$ Prof. Dr. Marmara Üniversitesi Eğitim Fakilltesi, mcdogan@marmara.edu.tr \\ ${ }^{3}$ Dog.. Dr. Marmara Üniversitesi Eğitim Fakültesi, mustafacakin@marmara.edu.tr
}

DOI: http://dx.doi.org/10.14582/DUZGEF.1816

ÖZ

Sınıf öğretmenlerinin alternatif ölçme ve değerlendirme hakkındaki görüşlerinin belirlenmesini amaçlayan bu araştırma nitel araşıırma yöntemlerinden durum çalışması deseninde tasarlanmıştır. Araştırmanın verileri 2011-2012 eğitimöğretim yllında görev yapan ve ölçüt örnekleme yöntemi kullanılarak belirlenen 9 sınıf öğretmeninden toplanmıştır. Araştırmada veri toplama aracı olarak yarı yapılandırılmış görüşme formu kullanılmış ve elde edilen veriler içerik analizi yöntemi kullanılarak incelenmiştir. Araştırmadan elde edilen sonuçlar sınıf öğretmenlerinin; alternatif ölçme ve değerlendirme ile ilgili ortak bir algısının olmadığını ve öğretmenlerin alternatif ölçme ve değerlendirme kavramı ile ilgili kavram karmaşası yaşadıklarını, alternatif ölçme ve değerlendirmenin öğrencilerin öz güvenini arttırdığını, kendilerini tanımalarını sağladığını ve arkadaşları ile kendilerini objektif olarak değerlendirebilmelerini sağladığını düşündüklerini göstermektedir.

Anahtar Kelimeler: sınıf öğretmenleri, ölçme ve değerlendirme, alternatif ölçme ve değerlendirme

\section{Determining Primary School Teachers' Perspectives of Alternative Assessment and Evaluation}

\begin{abstract}
The main aim of this qualitative case study was to determine primary school teachers' perspectives of alternative assessment and evaluation. Data of the study were collected during 2011-2012 school year. Participants were selected via criterion sampling method and consisted of nine primary school teachers. Semi-structured interview protocol was used as data collection instrument. Data were examined and analyzed with content analysis procedures. According to results of the study primary teachers do not share a common perception and understanding of alternative assessment and evaluation; they have conflicting conceptual perceptions of alternative assessment and evaluation and hold numerous misconceptions. Findings also suggest that primary teachers perceive that alternative assessment and evaluation practices enhance students' self-efficacy, enable them to know themselves better and improve their abilities to evaluate their and their peers' performances objectively.
\end{abstract}

Keywords: : primary school teachers, assessment and evaluation, alternative assessment and evaluation

\section{GİRİ̧̧}

Ölçme ve değerlendirme eğitim ve öğretimin ayrılmaz bir parçasıdır. Programdan beklenen faydanın sağlanıp sağlanmadığı, öğrencilerin bilgi, beceri ve tutumlarının gelişip gelişmediği ölçme ve değerlendirme vasıtası ile tespit edilir. Ölçme ve değerlendirme ile eğitim ve öğretim sürekli olarak izlenir, ortaya çıkan hata ve problemler tespit edilerek düzeltilir.

2005 ilköğretim programında öğrenme ve öğretme stratejileri yapılandırmacı anlayışa uygun olarak öğretmen merkezli bir yapıdan öğrenci merkezli bir yapıya doğru kaymıştır (MEB, 2005). Bu yön değişikliği ölçme ve değerlendirme yöntem ve tekniklerinin de değişmesini gerektirmiştir. Eski ilköğretim programında

\footnotetext{
* Bu çalışma, birinci yazar tarafından ikinci ve üçüncü yazarların danışmanlığında hazırlanan doktora tezinden üretilmiştir.
} 
geleneksel ölçme ve değerlendirme yöntemleri yer alırken, 2005 ilköğretim programı geleneksel ölçme ve değerlendirmenin yanında alternatif ölçme ve değerlendirme yöntemlerinin de uygulanmasını hedeflemiştir.

Alternatif ölçme ve değerlendirme, geleneksel kâğıt ve kalem testleri ile objektif testlerin dişındaki yöntemleri kapsamaktadır (McMillan, 2007). Alternatif ölçme ve değerlendirme yöntemlerinden bazıları; portfolyo, performans değerlendirme, proje çalışması, öz değerlendirme, akran değerlendirme, gözlem, görüşme, tanılayıcı dallanmış ağaç, yapılandırılmış grid ve kavram haritasıdır. Performans değerlendirme, proje çalışması gibi tekniklerin sınıflarda uygulanması ve karşılığında not verilmesi İlköğretim Kurumları Yönetmeliğince (MEB, 2012) zorunlu hale getirilmiştir.

2005 ilköğretim programının uygulanmasından itibaren programa yeni giren alternatif ölçme ve değerlendirme ve yöntemlerini konu alan birçok araştırma yapılmışır. Akata(2007), Algan (2008), Ataman (2007), Birgin (2010), Pınarbaşı (2007), Tabak (2007) ve Torçuk (2008) yeni ilköğretim programının ölçme değerlendirme boyutunun uygulanabilirlik düzeyini araştırmıştır. Karahan (2007), Mamur (2009) ve Uysal (2008) ise alternatif ölçme ve değerlendirme tekniklerinin uygulanmasını araştırmıştır. Birgin ve Gürbüz (2008), Kilmen, Kösterelioğlu ve Kösterelioğlu (2007) öğretmen adaylarının ölçme ve değerlendirme yeterlik algılarını rapor etmişlerdir. Öğretmenlerin ölçme ve değerlendirme yeterlik algıları Genç (2008), Gök ve Şahin (2009), Güneş (2007) ve Maral (2009) tarafindan çalışılımıştır. Arda (2009), Bal (2009), Çalışkan (2009), Okur (2008) ve Orhan (2007) alternatif ölçme ve değerlendirme tekniklerine ilişkin öğretmen görüşlerini incelemişlerdir.

Yukarıdaki araştırmalara bakıldığında alternatif ölçme ve değerlendirme hakkında birçok araştırmanın yapıldığı ancak bunların içinde öğretmen görüşlerini inceleyen çalışmaların azınlıkta olduğu görülmektedir. Ayrıca alternatif ölçme ve değerlendirme tekniklerine ilişkin öğretmen görüşlerini inceleyen çalışmalarda Bal (2009) 5. sınıf matematik dersini okutan sınıf öğretmenlerinin görüşlerini, Çalışkan (2009) fen ve teknoloji öğretmenlerinin görüşlerini, Okur (2008) 4. ve 5. sınıf fen ve teknoloji dersini okutan sinıf öğretmenlerinin görüşlerini, Orhan (2007) altıncı sınıf fen ve teknoloji öğretmenlerinin alternatif ölçme ve değerlendirme yöntemlerine ilişkin bakış açılarını incelemiştir. Bu araştırmalara göre sınıf öğretmenlerinin konu hakkındaki görüşlerini inceleyen ve ders odaklı olmayan araştırma sayısı oldukça azdır. Alternatif ölçme ve değerlendirme hakkında öğretmenlerin görüşlerinin belirlenmesi ile öğretmenlerin alternatif ölçme ve değerlendirme algıları, yaşadıkları problemler ve sebepleri vb. belirlenerek ilgili kurumların bu sorunları çözme noktasında adımlar atmasına ve konu üzerinde daha farklı çalışmalar yapılabilmesi için araştırmacılara 1şık tutulmasına çalışılacaktır. Bu bağlamda sınıf öğretmenlerinin alternatif ölçme ve değerlendirme hakkındaki görüşlerinin belirlenmesine ihtiyaç duyulmaktadır.

$\mathrm{Bu}$ araştırmanın ana amacı, sınıf öğretmenlerinin alternatif ölçme ve değerlendirme hakkındaki görüşlerinin belirlenmesindir. Bu ana amaca ulaşmak için aşağıdaki sorulara cevaplar aranmıştır.

1.Sınıf öğretmenlerinin alternatif ölçme ve değerlendirme algıları nedir?

2.Sınıf öğretmenlerinin alternatif ölçme ve değerlendirmenin faydaları hakkındaki görüşleri nelerdir?

3.Sınıf öğretmenlerinin alternatif ölçme ve değerlendirmenin geleneksel ölçme ve değerlendirmeye göre avantajları ve dezavantajları hakkındaki görüşleri nedir?

4.Sınıf öğretmenlerinin alternatif ölçme ve değerlendirmede karşılaştıkları problemler, sebepleri ve çözümlerine ilişkin görüşleri nedir?

\section{YÖNTEM}

$\mathrm{Bu}$ çalışmada nitel araştırma yöntemlerinden durum çalışması deseni kullanılmıştır. Araştırmacının kontrol edemediği durumlarda olgu veya olayın derinlemesine incelenmesini sağlayan bir yöntem olan durum çalışmasında nasıl, niçin ve ne (neler) sorularına cevap vermek temel amaçtır (Yıldırım ve Şimşek, 2011). Bu araştırmada da sınıf öğretmenlerinin alternatif ölçme ve değerlendirme hakkındaki görüşleri derinlemesine incelenmeye çalışılmıştır.

\section{1. Çalı̧̧ma Grubu}

Araştırmanın çalışma grubunu İstanbul ilinde bulunan üç farklı ilköğretim okulunda görev yapan 9 sınıf öğretmeni oluşturmaktadır. Çalısma grubunun belirlenmesinde amaçlı örnekleme yöntemlerinden ölçüt 
örnekleme yöntemi kullanılmıştır. Amaçlı örnekleme yönteminde, örnekleme dâhil olacak kişileri araştırmacı daha önceki bilgi, deneyim ve gözlemlerinden hareketle araştırmanın amacına uygun olarak kendi yargısıyla seçer. Araştırmacı kendi yargısıyla karar verdiği için evren hakkında bilgi sahibi olmalıdır (Ural ve Kılıç, 2006). Ölçüt örneklemede de araştırmacı tarafindan hazırlanan bazı ölçüt veya ölçütlere göre çalışma gurubunun belirlenmesi vardır (Yıldırım ve Şimşek, 2011). Çalışma grubunun belirlenmesinde kullanılan ölçütler sınıf öğretmenlerinin alternatif ölçme ve değerlendirme bilgi düzeyleri ve görev yaptıkları okulların sosyo-ekonomik düzeyleridir. Sınıf öğretmenlerinin alternatif ölçme ve değerlendirme bilgi düzeylerinin belirlenmesinde araştırmacının hazırlamış olduğu doktora tezinin verilerinden faydalanılmıştır. Bu ölçüte göre katılımcı öğretmenlerin ikisinin alternatif ölçme ve değerlendirme bilgi düzeyi yüksek, üçünün orta ve dördünün de düşüktür. Öğretmenlerin görev yaptıkları okulların sosyo-ekonomik düzeylerinin çalısma gurubunun belirlenmesinde ölçüt olarak alınmasının temel nedeni farklı düzeydeki okullarda görev yapan öğretmenlerin de görüşlerinden faydalanılması ve dengenin sağlanabilmesi içindir. Ayrıca sosyo-ekonomik düzeyi yüksekokullarda görev yapan öğretmenler daha kıdemli iken düşük okullarda daha genç öğretmenler görev yapmaktadır. Okulların düzeylerinin belirlenmesinde okul yöneticilerinin görüşleri alınmıştır. Bu ölçüte göre de üç öğretmen yüksek, üç öğretmen orta ve üç öğretmen de düşük sosyo-ekonomik düzeye sahip okullarda görev yapmaktadır. Çalışma grubunu oluşturan öğretmenlere ait demografik özellikler Tablo 1'de verilmiştir.

Tablo 1. Çalışma Grubunu Oluşturan Öğretmenlere Ait Demografik Özellikler (N=9)

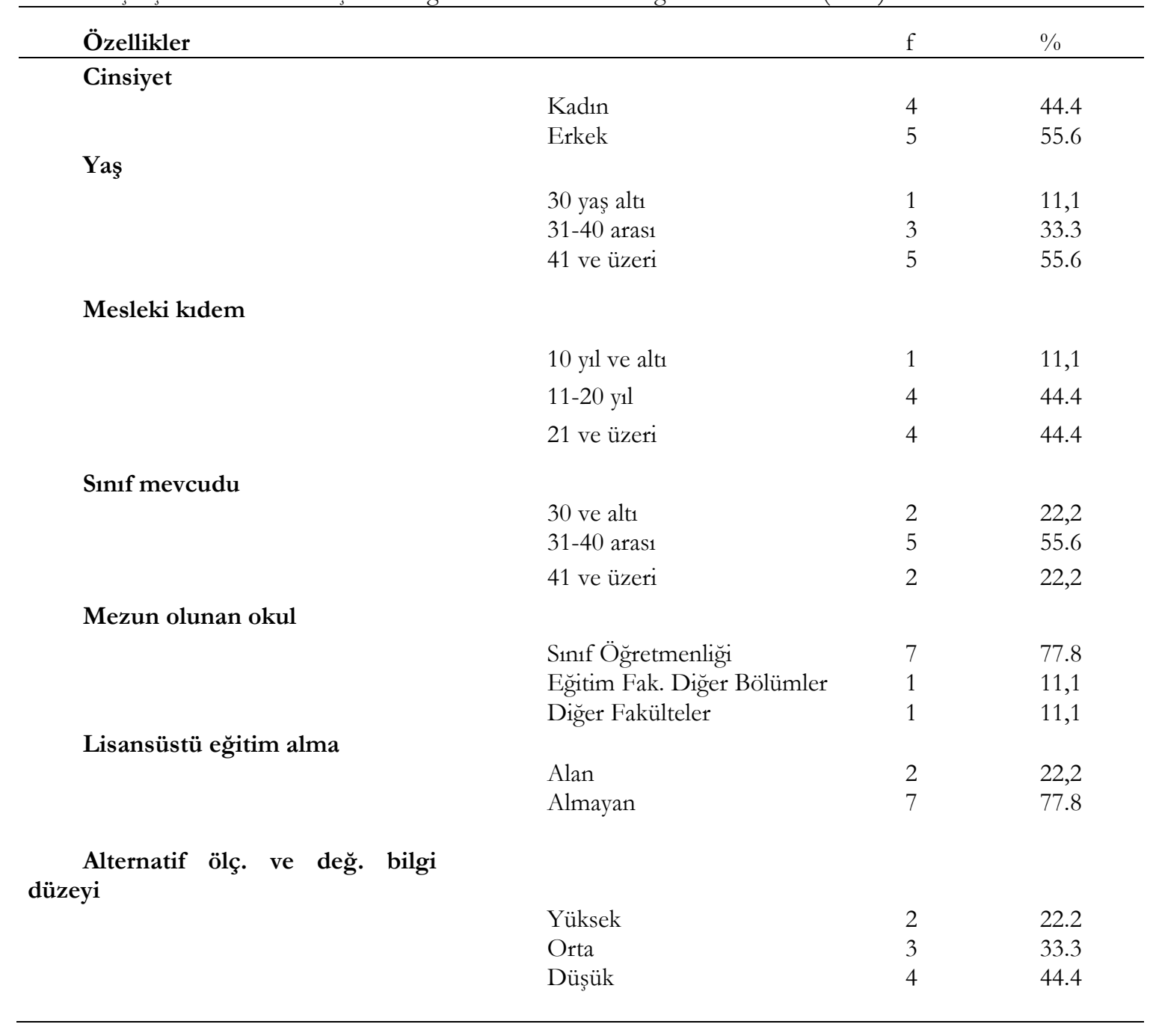

Tablo 1'de görüldüğü gibi çalışma grubunu oluşturan öğretmenlerden 4'ü kadın, 5’i erkektir. 1 öğretmen 30 yaş ve altında, 3 öğretmen 31-40 yaş aralığında ve 5 öğretmen ise 41 ve üzeri yaştadır. 1 öğretmen 10 yıl ve altı, 4’ü 11-20 yıl arası ve 4'ü de 21 yıl ve üzeri mesleki kıdeme sahiptirler. 2 öğretmen 30 ve altı öğrenciye, 5 öğretmen 31-40 arası öğrenciye ve 2 öğretmen de 41 ve üzeri öğrenci mevcuduna sahiptirler. 7 öğretmen sınıf öğretmenliğinden, 1 öğretmen eğitim fakültelerinin diğer bölümünden ve 1 öğretmen de eğitim fakültesi dışında bir fakülteden mezundur. Öğretmenlerden 3’ü üst sosyo-ekonomik, 3’ü orta ve 3’ü de alt sosyoekonomik düzeye sahip okullarda çalısmaktadır. Öğretmenlerin 2'si lisansüstü eğitim yapmış ve 7'side lisansüstü eğitim yapmamıştır. Katılımcı öğretmenlerden ikisinin alternatif ölçme ve değerlendirme bilgi düzeyi yüksek, üçünün orta ve dördünün de düşüktür. 


\subsection{Veri Toplama Araçları}

Araştırmanın verileri araştırmacı tarafından hazırlanan "kişisel bilgi formu ve yarı yapılandırılmış görüşme formu ile toplanmıştır. Kişisel bilgi formu; yaş, cinsiyet, mezun olunan okul, mesleki kıdem, sınıf mevcudu ve lisansüstü eğitim alma durumu olmak üzere 6 bağımsız değişkenden oluşmaktadır.

Karasar'a (2005) göre görüşmelerde görüşmenin türüne göre hazırlanmış bir kılavuzdan yararlanılır. Görüşme kılavuzu, görüşme sorularının belli bir sıra içinde bulunduğu, görüşmecinin uyması gereken kuralları hatırlatıcı ve kayıt işlemlerini kolaylaştırıcı bir şekilde hazırlanmalıdır. Karasar’a (2005, s. 169) göre görüşme k1lavuzunun hazırlanmasında dikkat edilmesi gereken bazı durumlar vardır:

a)İlk sorular ilginç ve cevaplaması kolay olmalı, kaynak kişiyi cevap vermeye güdülemelidir.

b)Sorular genelden özele doğru giden bir sırada sorulmalı.

c)Sorular uygun bir sıra içinde ve ilgilerine göre gruplanmış olmalı. Böylece kişinin daha ekonomik bir düşünme süreci içinde olmasına yardımcı olunur.

d)Bitiş soruları kaynak kişide "başarı duygusu "nu da bırakan, gerektiğinde yeni iş birliği için güdüleyen nitelikte olmalı.

Yarı yapılandırılmış görüşme formu hazırlanırken bu kurallara dikkat edilmeye çalışılmıştır. Görüşme formu hazırlanırken ilgili alan yazından ve sınıf öğretmenlerinin alternatif ölçme ve değerlendirme bilgi düzeylerinden yararlanılmıştır. Görüşme formunda ölçme ve değerlendirme ve alternatif ölçme ve değerlendirme ile ilgili sorular bulunmaktadır.

\subsection{Veri Toplama Araçları}

Yarı yapılandırılmış görüşme formu ile öğretmenlerin ölçme ve değerlendirme hakkındaki görüşleri alınmaya çalışılmıştır. Görüşme öncesinde öğretmenlere görüşme hakkında kısaca bilgi verilmiş ve görüşmelerin kayıt cihazı ile kayıt altına alınacağı bildirilmiştir. Görüşmelerde genel olarak bütün öğretmenlere aynı sorular sorulmuştur. Görüşmeler 50 dakika İle 75 dakika arasında sürmüştür. Görüşmeler öğretmenlerin görev yaptıkları okullarda boş bulunan sınıflarda ve öğretmenler odasında gerçekleştirilmiştir. Görüşmeler 2012 yılı Haziran ayında gerçekleştirilmiştir.

\subsection{Verilerin Çözümlenmesi}

Görüşme tekniği ile elde edilen verilerin çözümlenmesinde içerik analizi yöntemi kullanılmıştır. Yıldırım ve Şimşek (2011, s. 227)'e göre "içerik analizinde temel amaç, toplanan verileri açıklayabilecek kavramlara ve ilişkilere ulaşabilmektir. Bu çerçevede, içerik analizi yoluyla veriler tanımlanmaya, verilerin içinde saklı olabilecek gerçekler ortaya çıkarılmaya çalış1lır".

Görüşme yöntemi ile elde edilen verilerin çözümlenmesine, ses kayıt cihazı ile kaydedilen verilerin yazıya geçirilmesiyle başlanmıştır. Verilerin yazıya geçirilmesi yaklaşık üç aylık bir zaman diliminde gerçekleştirilmiştir. Dokuz öğretmenle yapılan verilerin yazıya geçirilmesiyle 80 sayfalık bir veri seti oluşmuştur. Daha sonraki süreçte verilerin okunmasına geçilmiştir. Veriler okundukça veri seti kendi içinde anlamlı birimlere ayrılmaya çalışılmıştır. Veriler anlamlı birimlere ayrıldıktan sonra bu birimlere kavramsal olarak ifade ettiği anlama göre bir isim verilmiştir. Yıldırım ve Şimşek (2011), veri setinin içinde anlamlı bir bütün oluşturan bölümlere araştırmacı tarafindan verilen isimlere kod adını vermektedir. Yapılan bu işlemede kodlama denilmektedir. Veri setinin kodlanması için veriler dört kez baştan sona okunmuştur. Verilerin okunması sırasında verilerin kenarlarına notlar alınmış ve veriler kodlanmaya devam edilmiştir. İlk önce verilerin kodlanması, verilerin daha kolay kodlanabileceği düşünülerek soru bazında verilen cevaplar üzerinde gerçekleştirilmiştir. Veri setinin tamamen kodlanmasından sonra kod listesi hazırlanmıştır. Kod listesi düzenlenmiş ve kontrol edilmiş, aynı ve benzer kodlar bir araya getirilerek veri seti düzenlenmiştir. Benzer veriler bir araya getirildikten sonra bunları açıklayabilen daha genel alt kategoriler ve kategoriler belirlenmiştir. Daha sonra ise benzer kategoriler bir araya getirilmiş ve bunları da daha genel olarak açıklayan tema belirlenmiştir. Kodların belirlenmesi sürecinde daha önce incelenen literatürden, araştırmacının tecrübelerinden ve veri setinin kendisinden de yararlanılmıştır. Temanın belirlenmesi sürecinde ise araştırmanın amaçlarından ve araştırma sorularından faydalanılmış ve araştırmanın amaçları ile temanın ilişkili olması sağlanmıştır. 
$\mathrm{Bu}$ süreçlerden sonra kategori bazında tablolar oluşturularak verilerin yorumlanmasına geçilmiştir. Tablolarda görüşme yapılan öğretmenlerin gerçek isimlerine yer verilmemiş Ö1, Ö2 şeklinde kodlama yapılmıştır. Veriler yorumlanırken görüşme kayıtlarından doğrudan alıntılar yapılmış ve alıntıların hangi öğretmenden ve görüşmelerin yazılı halinin kaçıncı sayfasından alıntı yapıldığı parantez içinde verilmiştir. Örneğin (Ö1, s.3), 1 numaralı öğretmenden elde edilen veri setinin üçüncü sayfasından alıntı yapıldığını ifade etmektedir.

Görüşmelerden elde edilen verilerin çözümlenme süreci Collins’in (1999, akt. Yıldırım ve Şimşek, 2011, s.239) çerçevesi temel alınarak aşağıdaki şekilde gösterilmiştir.

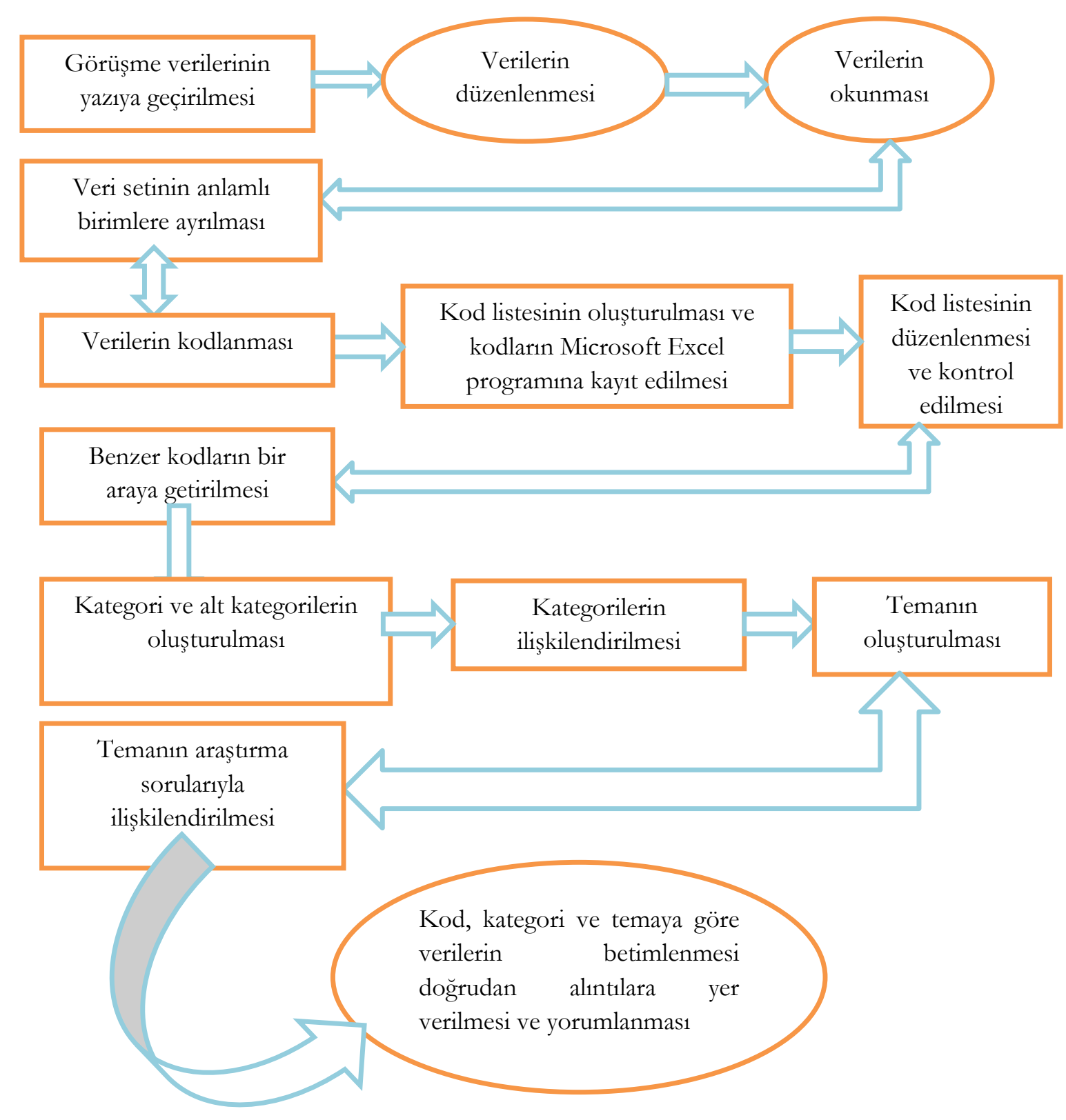

Şekil 1. Görüşmeden Elde Edilen Verilerin Analiz Süreci

\section{BULGULAR}

Araştırma soruları ve toplanan verilerin analizi aşağıda tablolar halinde sunulmuştur. Alt kodların, kodların, alt kategorilerin ve kategorilerin birlikte değerlendirilmesi neticesinde "Sınıf Öğretmenlerinin Alternatif Ölçme ve Değerlendirme Hakkındaki Görüşleri” ile ilgili çıkarımlar yapılmıştır.

Araştırmanın birinci sorusuna cevap verebilmek amacıyla sınıf öğretmenlerinin alternatif ölçme ve değerlendirme algılarını belirlemek için yapılan analizin sonucu Tablo 2'de verilmiştir. 
Tablo 2. Sınıf Öğretmenlerinin Alternatif Ölçme ve Değerlendirme Alg1ları

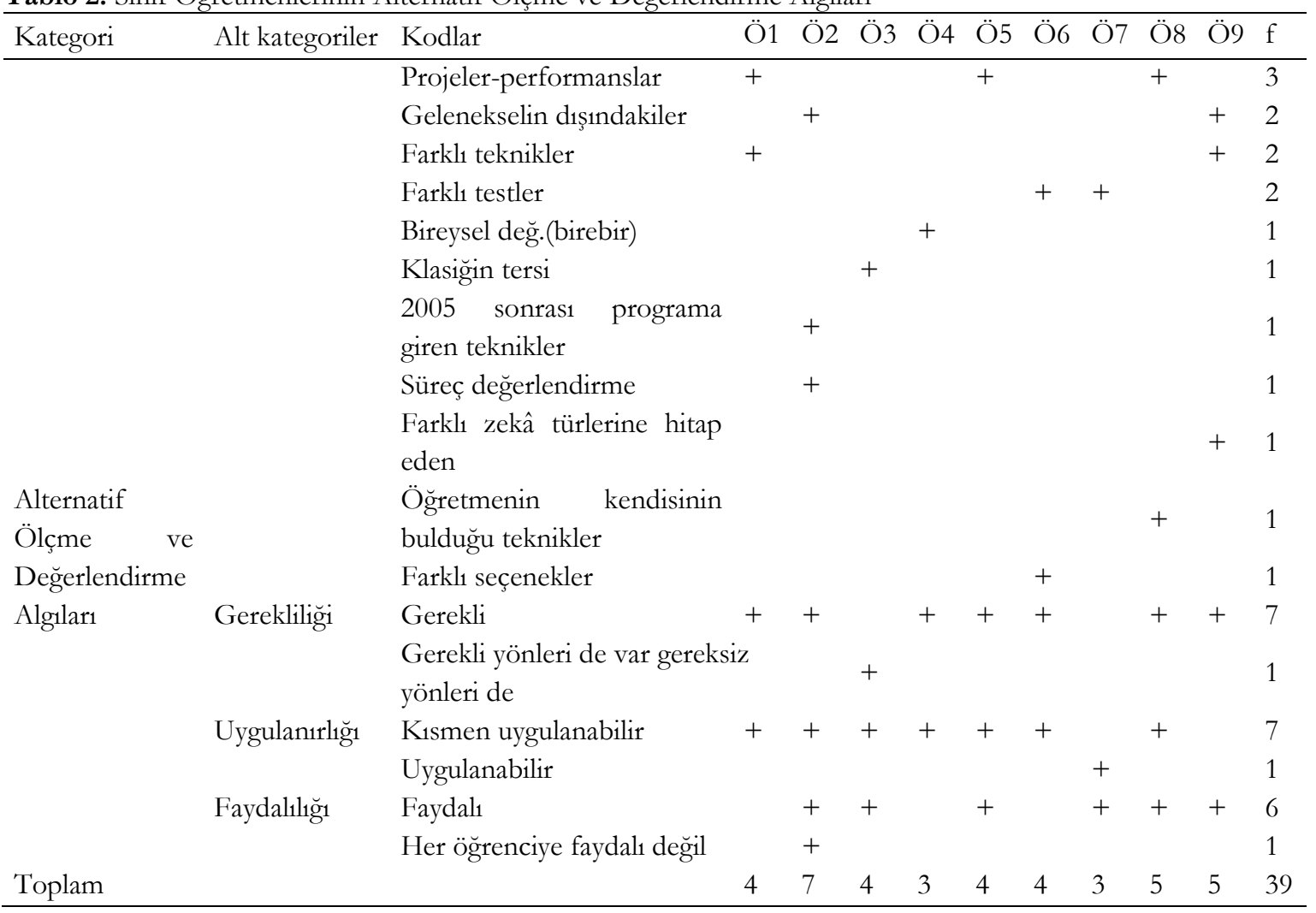

Görüşmeye katılan sınıf öğretmenlerinin alternatif ölçme ve değerlendirme algıları incelendiğinde, öğretmenlerin alternatif ölçme ve değerlendirmeyi zihinlerinde tam olarak bir yere oturtamadıkları ve ortak bir kavram üzerinde buluşamadıkları görülmektedir. Katılımcılar alternatif ölçme ve değerlendirmeden ne anliyorsunuz sorusuna bir birinden farklı on bir adet kavramla cevap vermişlerdir. Bu durum bize öğretmenlerin üzerinde ortak olarak anlaştığı bir kavram olmadığını göstermektedir. Dokuz öğretmenden sadece üçü "projeler-performanslar" kavramı üzerinde buluşmuşlardır. Diğer kavramlar da ikişer ve birer öğretmen tarafindan ifade edilmiştir.

Yukarıda öğretmenler tarafindan ifade edilen kavramlardan "farklı testlerdir" kavramı haricinde diğerlerinin hepsinin alternatif ölçme ve değerlendirme ile bir bağlantısı bulunmaktadır. Alternatif ölçme ve değerlendirmeyi farklı testlerdir şeklinde ifade etmek, alternatif ölçme ve değerlendirmenin geleneksel ölçme ve değerlendirme ile karıştırılmasından ve temelde ikisi arasındaki farkın anlaşılamamasından kaynaklanmaktadır. Dokuz öğretmenden iki öğretmenin bu şekilde düşünmesi de üzerinde durulması ve sorgulanması gereken bir durumu göstermektedir. Ö6 alternatif ölçme ve değerlendirmeyi öğrencilere seçme şansının olduğu durumlanı sunmak olarak algıladığını ifade etmektedir. Bu düşünceye göre öğrencilere sunulan birden fazla test türü sınav, çalışma kâğıdı vb.de alternatif ölçme ve değerlendirmedir. Ö6'nın düşünceleri şu şekildedir: “...Alternatif dediğgin zaman seşenekler daha değişik diye anliyorum... Alternatif olarak araştırmak, diğer kaynaklara da yönelmek laz̧ım. Testlerde kullanyoru₹: Alternatif olarak test kullanyyoruz...” (Ö6, s. 2-3).

Her öğretmenin zihninde alternatif ölçme ve değerlendirme farklı bir yerde durmaktadır. Bazı öğretmenler alternatif ölçme ve değerlendirmeyi öğrencilerin birebir değerlendirilmesi olarak görürken bazıs1 da öğretmenin kendisinin keşfettiği, daha önce bilinmeyen teknikler olarak görmekte bazıları da geleneksel ölçme ve değerlendirmelerin dışındaki ölçme ve değerlendirme teknikleri olarak görmektedir. Görüşme yapılan her öğretmenin zihninde buna yönelik bir alternatif ölçme ve değerlendirme tanımı bulunmaktadır. Ö1 ve Ö3 alternatif ölçme değerlendirmeyi sınıftaki öğrenme ortamının durumuna göre öğretmenler tarafindan işe koşulması gereken öğrenme etkinlikleri şeklinde düşünmektedirler. Ö1 alternatif ölçme ve değerlendirmeyi şu cümlelerle ifade etmiştir:

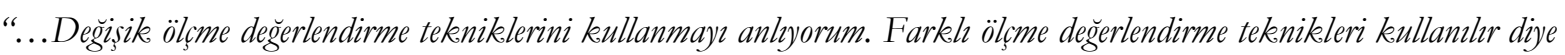
düşünüyorum. Bunlar ne olabilir, baz̧en mesela bu kullandiğımı ölçme değerlendirme teknikleri işe yaramayabilir. Aile ile

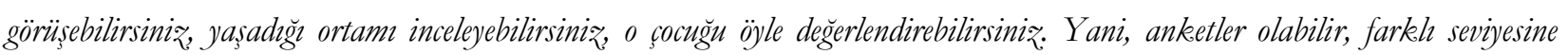
uygun etkinlikler olabilir. Yani sinfa bir tek etkinlik uyguluyorsunuz, belki o çocuk o etkinlikten boşlanmayabilir. Onu 
ögrenemeyebilir, farkl etkinlikler hazırlanabilir. O çocuğa yönelik, onun ögrenme durumuna göre. Mesela görsel, işitsel. Cocuk nasıl ögreniyorsa o tespit edilebilir. Ona göre bir değerlendirme yapılabilir...” (Ö1, s. 2).

Katılımcıların, zihinlerinin karışık olmasına rağmen genel olarak alternatif ölçme ve değerlendirmenin gerekli ve faydalı olduğunu düşünmektedirler. Ö3 ise alternatif ölçme ve değerlendirmenin gerekli olduğunu ancak şuan ki sistemde gereksiz bazı taraflarının olduğunu da ifade etmektedir. Ö3’e göre eğitim sisteminin sınav odaklı olması alternatif ölçme ve değerlendirmeden beklenen faydanın gelmemesine ve bütün derslerde uygulanması da yüzeysel olarak uygulanmasına neden olmaktadır. Ö3 bu görüşlerini şu cümlelerle ifade etmiştir:

“...yani çok benim adima gerekli miydi gerekli değil miydi demektense gerekli olan yönleri de var gereksiz olan yönleri de var. Bütün olarak değerlendirmek gerekiyor. Mesela bu sistemin sonucunda SBS gibi sinavlar olduğu sürece sonucta çocuk orda kaliyor...Bazı derslere yönelik olsa bence daba iyi olur. Mesela 4. Siniftayken matematik ve Türkece dersinde sadece bu alternatif teknikler yapulsın. Onlarla değerlendirilsin. Ama sen sosyali fen ve teknoloji dersini her şeyi katınca o asıl yapman donanıml olarak yapacağın dĭger şeyler de geri kalyyor gibi geliyor bana. Yüzeysel kaliyor o zaman. Bu sefer onun üzerinde yoğunlaşamaynca bepsi de böyle eften püften bir şeyler oluyor...” (Ö3, s. 4-5).

Ö1 ve Ö8 alternatif ölçme ve değerlendirmeden bahsederken sınıf öğretmenlerinin branş öğretmenlerine göre ölçme ve değerlendirme noktasında daha şanslı olduklarını düşünmektedirler. Bunun nedeni olarak da sınıf öğretmenlerinin aynı sınıfı dört yıl süreyle okutmasından dolayı o sınıftaki öğrencileri her yönüyle tanıma imkânına sahip olmalarını görmektedirler. Öğrenci hakkında bu kadar bilgi sahibi olmalarından dolayı Ö8 alternatif ölçme ve değerlendirme ve tekniklerine çok da fazla ihtiyaç olmadığını düşünmektedir. Ö8 bu durumu şu cümlelerle ifade etmektedir:

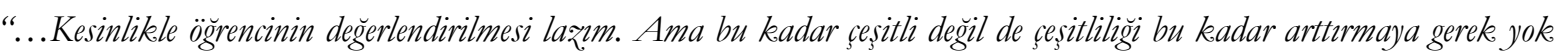

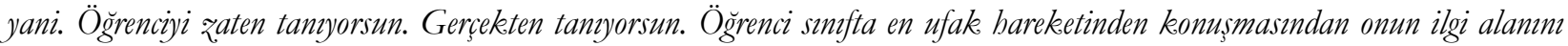
görüyorsun. Ağaçt bilmem neydi onlar büyüklere yapsinlar. Bunlar çok küçük. Sınf ögretmeni net olarak görüyor. Gerek yok..." (Ö8, s. 3).

Katılımcıların geneli alternatif ölçme ve değerlendirmenin gerekli ve faydalı olduğunu düşünürken uygulanabilirlik noktasında düşüncelerini olumsuz biçimde ifade etmişlerdir. Öğretmenlerin, tekniklerin uygulanabilirliği ile ilgili olumsuz düşünmelerinin nedenleri arasında genel olarak sınıf mevcutlarının kalabalık olması, programın yoğunluğu ve zamanın yetmemesi bulunmaktadır. Ö2’nin bu konu hakkındaki düşünceleri şu şekildedir: “...Programdaki konu yükü oldukesa fąla. Zaten müfredat kapsamında konularn yetiştirilmesi süre olarak bizi sıkıntıya sokuyor. Bunun haricinde alternatif ölçme ve değerlendirmeye bizden oldukça zaman ayırmamız̨ istiyor... Uzun bir süre ayıryoruz, birde müfredatın oldukeça sıkısmasına neden oluyor. Öğretmeni- ögrenciyi sıkıntıya sokmaktadır... programdaki yük.ün de faحlalı̆̆ bu yöntemlerin kullanılabilirliğini olumsuz manada etkiliyor...” (Ö2, s. 5-6). Ayn1 şekilde düşünen Ö5'in düşünceleri de şu şekildedir: “...Uygulanabilirliğinde biraz sıkıntı var. En büyüle sıkıntıda zaman ve sinflarm kalabalık olması..." (Ö5, s. 3).

Araştırmanın ikinci sorusu, sınıf öğretmenlerinin alternatif ölçme ve değerlendirmenin faydaları hakkındaki görüşlerini belirlemeye yöneliktir. Bu soruya cevap verebilmek amacıyla yapılan analizlerin sonucu Tablo 3 a ve $3 b$ de verilmiştir. 
Tablo 3a. Sınıf Öğretmenlerinin Alternatif Ölçme ve Değerlendirmenin Öğrenciye Faydalarına İlişkin Görüşleri

\begin{tabular}{|c|c|c|c|c|c|c|c|c|c|c|c|c|c|}
\hline Kategori & $\begin{array}{l}\text { Alt } \\
\text { kategori }\end{array}$ & Kodlar & Alt kodlar & Ö1 & Ö2 & Ö3 & Ö4 & Ö5 & Ö6 & Ö7 & Ö8 & Ö9 & $\mathrm{f}$ \\
\hline & & Öz güven & & + & + & + & + & + & + & & + & + & 8 \\
\hline & & Arkadaşlarını & & & & & & & & & & & \\
\hline & & değerlendirebilme & & & + & + & + & + & + & & + & + & 7 \\
\hline & & $\begin{array}{l}\text { Kendini } \\
\text { değerlendirme }\end{array}$ & & + & + & + & + & & + & & & + & 6 \\
\hline & & Ürün oluşturma & & + & + & + & + & & + & & & & 5 \\
\hline & & İletişimin artması & & + & + & & & + & + & & + & & 5 \\
\hline & & Sosyalleşme & & + & + & + & & & + & & & & 4 \\
\hline & & $\begin{array}{l}\text { Kendini ifade } \\
\text { etme }\end{array}$ & & & + & + & & + & + & & & & 4 \\
\hline & & $\begin{array}{l}\text { Sunum yapmay1 } \\
\text { öğrenme }\end{array}$ & & & & + & & + & & & + & + & 4 \\
\hline & & Yaratıcilik & & + & + & & & & + & & & & 3 \\
\hline & & $\begin{array}{l}\text { Eksiğini } \\
\text { tamamlama }\end{array}$ & & & + & & & + & & & & + & 3 \\
\hline & & Başarının artması & & & & & & + & & + & & + & 3 \\
\hline & Öğrenciye & Paylaşım & & + & & & & + & & + & & & 3 \\
\hline & & $\begin{array}{l}\text { Hitabetin } \\
\text { gelişmesi }\end{array}$ & & & + & & & + & & & + & & 3 \\
\hline & & El becerisi & & + & + & & & & & & & & 2 \\
\hline $\begin{array}{l}\text { Alternatif Ölçme } \\
\text { ve }\end{array}$ & & Düzeni öğrenme & & & & & & & + & & & + & 2 \\
\hline \multirow[t]{7}{*}{$\begin{array}{l}\text { Değerlendirmenin } \\
\text { Faydaları }\end{array}$} & & $\begin{array}{l}\text { Sorumluluk almayı } \\
\text { öğrenme }\end{array}$ & & + & & & & & & & & + & 2 \\
\hline & & & $\begin{array}{l}\text { Kendini } \\
\text { tanıma }\end{array}$ & + & + & + & + & & + & & + & + & 7 \\
\hline & & & Araştırma & + & + & + & & + & & & & + & 5 \\
\hline & & düzey & $\begin{array}{l}\text { Problem } \\
\text { çözme }\end{array}$ & & + & + & & & + & & & + & 4 \\
\hline & & öğrenme & $\begin{array}{l}\text { Eleştirel } \\
\text { düşünme }\end{array}$ & & + & + & & & + & & & & 3 \\
\hline & & & $\begin{array}{l}\text { Ayrintılı } \\
\text { düşünme }\end{array}$ & + & & & & & + & + & & & 3 \\
\hline & & & $\begin{array}{l}\text { Bilimsel } \\
\text { yöntem }\end{array}$ & & + & + & & & & & & & 2 \\
\hline Toplam & & & & 12 & 16 & 12 & 5 & 10 & 13 & 3 & 6 & 11 & 88 \\
\hline
\end{tabular}

Katılımcıların alternatif ölçme ve değerlendirmenin faydaları hakkındaki görüşleri incelendiğinde öğrenciye, öğretmene ve veliye olan faydaları üzerinde görüş bildirdikleri görülmektedir.

Katılımcılar alternatif ölçme ve değerlendirmenin öğrencilere onların öz güvenini arttırması, arkadaşlarını ve kendilerini objektif olarak değerlendirebilmeyi sağlaması yönünden yararlı olduğunu belirtmişlerdir. Ö1, geleneksel ölçme ve değerlendirme ile alternatif ölçme ve değerlendirmeyi kıyaslarken bu yöndeki düşüncesini şu cümlelerle ifade etmiştir: “...Ama şimdi öyle değil. Herkes en ažndan o konuyla ilgili yapabildiğini yapyyor. Biri resim 
yapyor, soru haz̧rlyyor bir diğeri yarm kalan bir öyküyü tamamlyyor. Herkes bir şeyler yaptuğ için şey de yok. Öbür türlü çocuk yapamyyorum diye kenara çekiliyordu. Şimdi en ažndan ben de bir şeyler yapayorum deyip kendine güveni artiyor diye düşünüyorum...” (Ö1, s. 3).

Ayrıca, genel olarak öğretmenler öğrencilerin değerlendirme kabiliyetlerinin de gelişeceğini düşünmektedir. Bu değerlendirme becerileri hem kendini hem de arkadaşlarını değerlendirebilmedir. Ö2 öğrencilerin, arkadaşlarını ve arkadaşlarının kendilerini değerlendirmesi sonucunda birbirlerini daha iyi tanıdıklarını, kendi eksikliklerinin farkına vardıklarını ve takdir etmeyi ve edilmeyi öğrendiklerini düşünmektedir. Ö2 bu düşüncelerini şu cümlelerle ifade etmiştir:

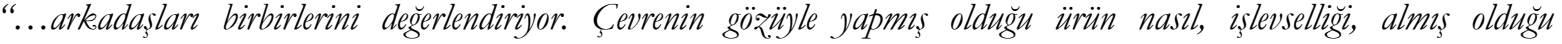
değerlendirmesi, gerçekten yapmıs olduğu çalısma kayda değer mi? Bunu çocuk fark edecektir. En az̦ndan eksikliklerini

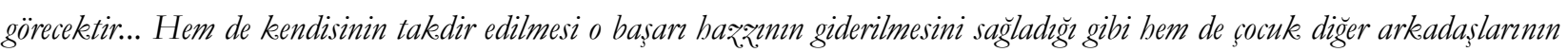
çalısmalarm değerlendireceği için değerlendirme yeteneği gelişecek onlar takdir edecek ve takdir etmeyi ve edilmeyi ögrenecek..." (Ö2, s. 5).

Katılımcılar genel olarak alternatif ölçme ve değerlendirmenin öğrencilere üst düzey öğrenme becerileri kazandıracağını düşünmektedir. Öğretmenlerin genelinin üzerinde durduğu üst düzey öğrenme becerisi ise öğrencinin kendini tanımasıdır Ö4 bu yöndeki düşüncesini şu şekilde ifade etmiştir: “...Kendi yeteneğini kessfetme imkâm bulacak sę̧me imkâm tanıd̆ğmı zaman. Hangi derslerde daha çok yetenekli olduğunu, ilgisi olduğu noktasinda bir farkındalk yaratacaktır...” (Ö4, s. 4-5).

Tablo 3b. Sınıf öğretmenlerinin alternatif ölçme ve değerlendirmenin öğretmene ve veliye faydalarına ilişkin görüşleri

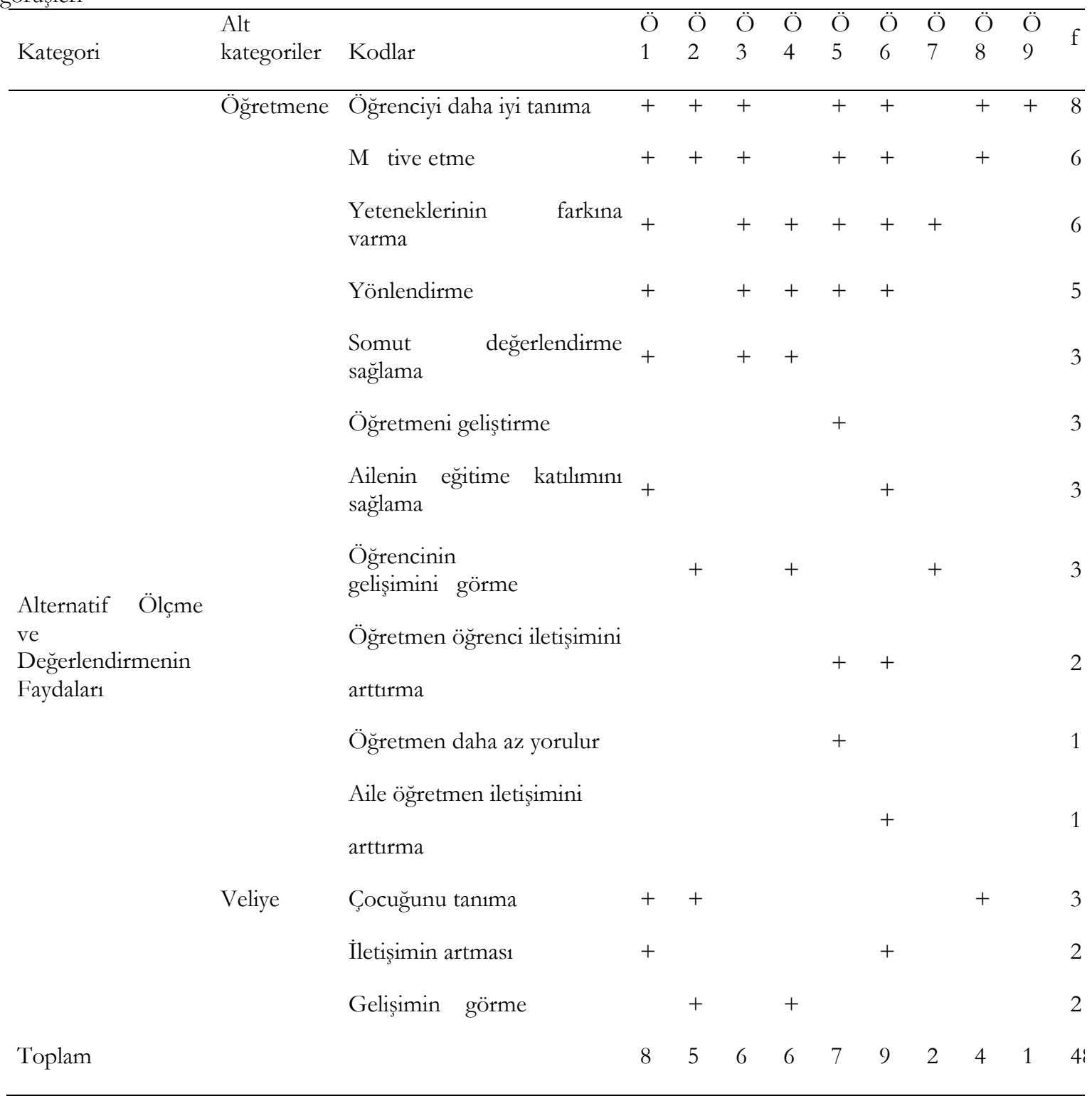

Katılımcıların öğretmene faydaları hakkındaki görüşleri incelendiğinde; öğrenciyi daha iyi tanıma, motive etme ve yeteneklerinin farkına varma üzerinde daha çok vurgu yaptıkları görülmektedir. Ö2 ve Ö4 alternatif ölçme ve değerlendirme ile öğrencilerin akademik başarılarının neyin arttırdığını, azalttığını ve bunların 
nedenlerinin neler olduğunu tespit ettiklerini ifade etmektedirler. Ö2 bu düşüncesini şu cümlelerle ifade etmektedir: "...çocuk hangi konuda duraksad, hangi konuda ilerledi çalssması neden geriledi veya hangi yöntemler teknikler

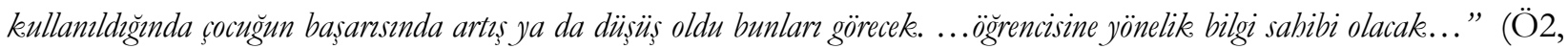
s. 6). Katılımcılar çoğunlukla alternatif ölçme ve değerlendirmenin öğrencileri okula ve derslere yönelik motive ettiğini düşünmektedirler. Ö1, Ö3 ve Ö8 bu teknikleri öğrencilerin ilgisini çektiğini ve bundan dolayı derslerin daha eğlenceli geçtiğini düşünmektedirler. Ö8 öğrencilerin yaptıkları bu çalışmalar ile öğrenme ortamını sınıfın dışına taşıdıklarını ve ögrenciler kadar kendisinin de bundan hoşlandığını ifade etmektedir. Ö8'in bu konu hakkındaki düşünceleri şu şekildedir: "...Ş̈̈lle diyeyim. Mesela slayt hažrlyyor çocuklar güzel slaytlar. Hareketlilik. getiriyor. Veya sunum yapzyorlar. O sunumda sanki bir sabne gösterisi varmıs gibi düşünüyorlar. Mevsimler sunusunu yaptım bende müthiş zevk aldim...” (Ö8, s. 3-4).

Katılımcı öğretmenler çoğunlukla, alternatif ölçme ve değerlendirmenin öğrencilerin yeteneklerinin belirlenmesine yardımcı olduğunu düşünmektedir. Ö4 çoklu zekâ teorisine atıfta bulunarak bu değerlendirme ile öğrencilerin ilgi ve yeteneklerinin ortaya çıtığını düşünmektedir. Bu düşüncesini şu cümlelerle ifade

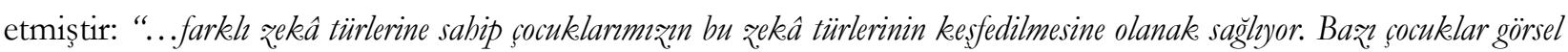
ögrenen, kinestetik, duygusal, sosyal yönden üstünlüklerini ya da farklhlklarm görebiliyoruz. Cocuğun hangi yönde daha yetenekli olduğunu ve ilgisi olduğunu görebiliyoruz...” (Ö4, s. 5-6). Ö7 ise konuya geleneksel ölçme ve değerlendirmenin bakış açısı ile bakmaktadır. Ö7 Alternatif ölçme ve değerlendirme ile öğrencilerin zekâ kapasitelerinin belirleneceğini ve bilgilerin kapasitelerine uygun bir biçimde düzenlenerek öğrencilere öğretileceğini düşünmektedir. Ö7'nin düşünceleri şu şekildedir: “...ne derece algılayabildiğini, zekâ kapasitesini anlyyoru‡, verilecek bilgileri ona göre ayarlyoru₹...” (Ö7, s. 2). Bu durum bize geleneksel ölçme ve değerlendirme anlayışının bazı öğretmenlerin zihinlerinde kalıı biçimde durduğunu göstermektedir.

Ö5 ise alternatif ölçme ve değerlendirmenin farklı bir faydasını dile getirmiştir. Ö5 bu değerlendirme ile daha az yorulduğunu, kendisinin pasif öğrencilerin aktif durumda olduğunu dile getirmektedir. Ö5 bu düşüncesini şu şekilde ifade etmiştir: “...Benim açımdan bir faydası da var derslerde daha az yoruluyorum. Ne yapıyorum ben orda sadece ögrenciler birbirleri ile iletișim kurarken, anlatrkeen orda sadece lider, yönlendirici, yerine göre devreye giren, yerine göre işte sö̋lerini kesmeden iște burada böyle olmalyyd gibi anlatımlarn tamamlayan bir rebber ögrretmen gibi görev görïyorum, benim için faydası o...” (Ö5, s. 6). Burada yanlış olan, bu değerlendirme yönteminde öğrencinin aktif öğretmenin pasif olmasından dolayı öğretmenlerin geleneksel ölçme ve değerlendirme yöntem ve tekniklerine göre daha az yorulması düşüncesidir. Çünkü alternatif ölçme ve değerlendirme yöntem ve tekniklerini gerçekten uygulayan bir öğretmen çok daha fazla yorulmak durumunda kalacaktır. Bu yöntem ve teknikleri hazırlanması, uygulanması ve değerlendirilmesi bir süreci ifade eder ve bu süreçte en aktif durumda olan yine öğretmendir.

Katılımcılar alternatif ölçme ve değerlendirmenin veliye faydaları noktasında öğretmene ve öğrenciye faydalarına oranla çok daha az sayıda düşünce belirtmişlerdir. En fazla vurgu yapılan görüş ise velinin çocuğunu tanımasına yardımcı olmasıdır. Bu görüş ancak üç öğretmen tarafindan, iletişimin artması ve gelişimini görme ise ikişer öğretmen tarafindan ifade edilmiştir.

Araştırmanın üçüncü sorusu, sınıf öğretmenlerinin alternatif ölçme ve değerlendirmenin geleneksel ölçme ve değerlendirmeye göre avantajları ve dezavantajları hakkındaki görüşlerini belirlemeye yöneliktir. Bu soruya cevap verebilmek amacıyla yapılan analizlerin sonucu Tablo 4a ve 4b'de verilmiştir. 
Tablo 4a. Sınıf öğretmenlerinin alternatif ölçme ve değerlendirmenin geleneksel ölçme ve değerlendirmeye göre avantajlarına ilişkin görüşleri

\begin{tabular}{|c|c|c|c|c|c|c|c|c|c|c|c|}
\hline Kategori & Kodlar & Ö1 & Ö2 & Ö3 & Ö4 & Ö5 & Ö6 & Ö7 & Ö8 & Ö9 & $\mathrm{f}$ \\
\hline \multirow{9}{*}{ Avantajlar1 } & Farklı zekâ türlerine hitap etme & + & & + & + & + & + & + & & + & 7 \\
\hline & Çocuğun sevmesi & + & + & & & + & & & + & + & 5 \\
\hline & Süreci değerlendirme & & + & & + & + & + & & & & 4 \\
\hline & Üst düzey öğrenmeyi sağlama & + & + & + & & & + & & & & 4 \\
\hline & Motivasyon sağlama & & + & & & + & + & & & & 3 \\
\hline & Yaparak yaşayarak öğrenme & & + & + & & + & & & & & 3 \\
\hline & Somut değerlendirme & + & & & + & & & & & & 2 \\
\hline & Objektif değerlendirme & + & & & + & & & & & & 2 \\
\hline & Ailenin eğitimi & + & & & & & + & & & & 2 \\
\hline Toplam & & 6 & 5 & 3 & 4 & 5 & 5 & 1 & 1 & 2 & 32 \\
\hline
\end{tabular}

Katılımcıların alternatif ölçme ve değerlendirmenin geleneksel ölçme ve değerlendirmeye göre avantajları hakkındaki görüşleri incelendiğinde, öğretmenlerin genel olarak alternatif ölçme ve değerlendirmenin öğrencilerin farklı zekâ türlerine hitap ettiğini vurguladıkları görülmektedir. Ö1, Ö3, Ö7 ve Ö9 bu yöntem ve tekniklerin çeşitli olmasından dolayı farklı becerilere sahip çocuklara hitap ettiğini ve bunun neticesi olarak da bu tür çalışmaların çocukların ilgisini çektiğini ifade etmişlerdir. Ö1 bu yöndeki düşüncesini şu cümlelerle ifade etmiştir: "...Ilgi alanı, žekâ durumuna göre, çoklu žekâ yöntemleri kullanullyor oda güzel. Önceden neydi bu dördüncü simf ben buna şunlar vermek, zorundayım. Şimdi ne diyorsun bu çocuk ancak bu kadar ögrenebilir, bunu ögrenebilir diyorsun. O da kendi z̧ekâsına uygun çalısmalar yapıyor. Farkh žekâ türlerine bitap ediyor...” (Ö1, s. 4). Ö9'da başarısı etiketi vurulan bir çocuğun bile başarabildiği bir şeylerin olduğunu ortaya çıkardığını düşünmekte ve farklı ölçme ve değerlendirme tekniklerinin uygulanmasının öğrencilerin daha çok ilgisini çektiğini dile getirmektedir. 
Tablo 4b. Sınıf öğretmenlerinin alternatif ölçme ve değerlendirmenin geleneksel ölçme ve değerlendirmeye göre dezavantajlarına ilişkin görüşleri

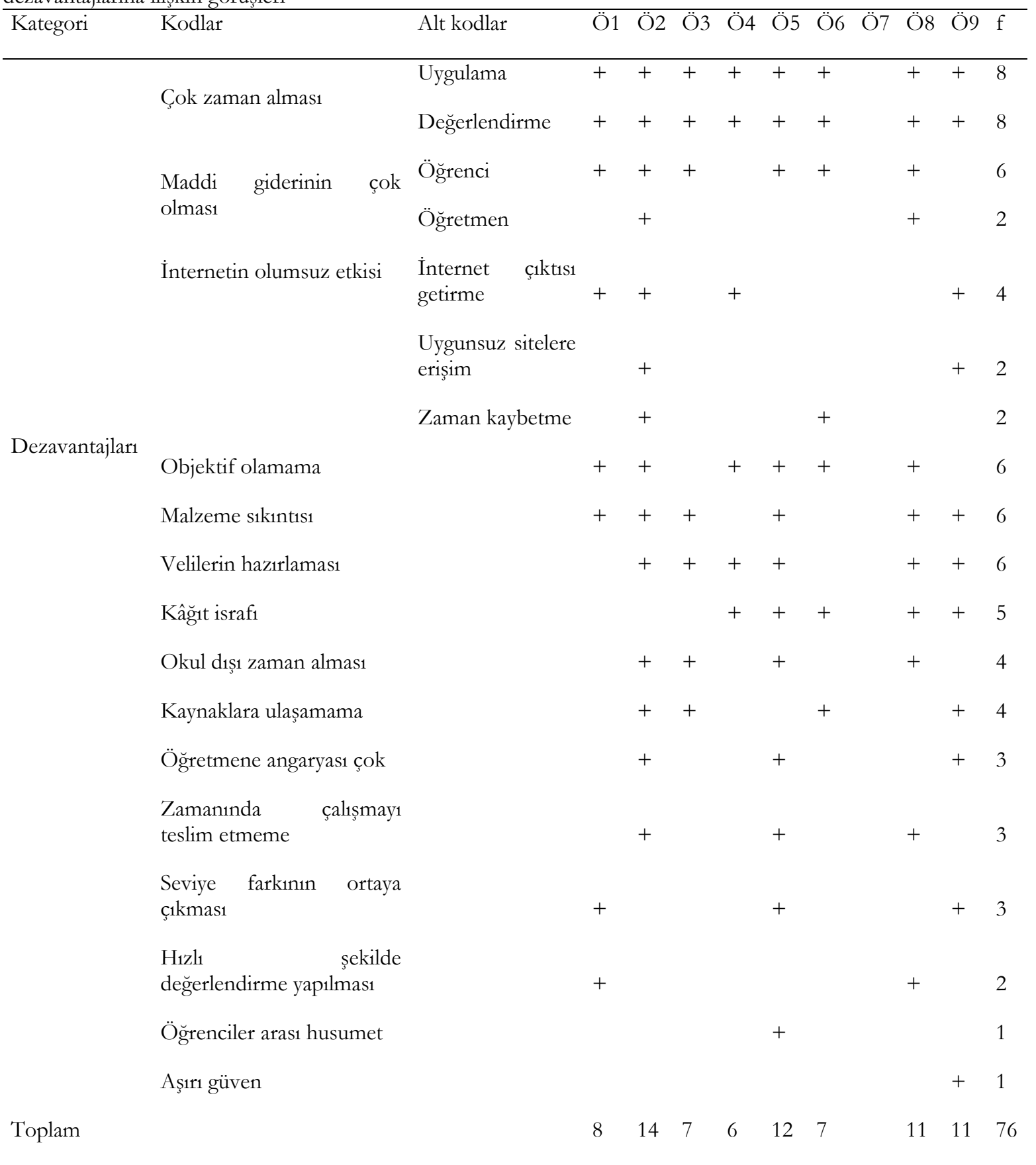

Katılımcıların; alternatif ölçme ve değerlendirmenin geleneksel ölçme ve değerlendirmeye göre avantajları ve dezavantajları hakkındaki görüşleri incelendiğinde alternatif ölçme ve değerlendirmenin dezavantajlarına daha fazla vurgu yaptıkları görülmektedir. Bu pencereden bakıldığı zaman öğretmenlerin geleneksel ölçme ve değerlendirmeyi daha avantajlı olarak gördükleri söylenebilir. Aynı şekilde öğretmenlerin dile getirmiş olduğu dezavantajlar incelendiğinde birçoğunun öğretmenlerin alternatif ölçme ve değerlendirme hakkında yeterince bilgi sahibi olmaması ve bunun neticesi olarak da bu teknikleri etkili bir biçimde uygulayamamalarından kaynaklandığı görülmektedir.

Katılımcıların genel olarak alternatif ölçme ve değerlendirme yöntem ve tekniklerinin öğrencilere uygulanmasının ve elde edilen verilerin değerlendirilmesinin çok zaman aldığı üzerinde yoğunlaştıkları görülmektedir. Öğretmenler bu yöntem ve tekniklerin çok zaman almasının temel nedeni olarak sınıf mevcutlarının kalabalık olmasını görmektedirler. Bu noktada öğretmenlerin haklı olduğunu söylemek gereklidir. Çünkü bu değerlendirmede esas olan eğitim öğretim sürecinin değerlendirilmesidir ve süreç değerlendirmesini 35-40 kişilik sınıflarda gerçekleştirmek oldukça zordur. Ö2 geleneksel ölçme ve değerlendirmede yaptığı bir sınavın değerlendirmesinin fazla bir zamanını almadığını belirtirken alternatif ölçme ve değerlendirme yöntem ve tekniklerinin uygulanmasının ve değerlendirilmesinin günlerini aldığını ve bunun içinde okul dışında da zaman harcadığını dile getirmektedir. Ö2 bu düşüncesini şu şekilde ifade etmiştir: “...Bunun haricinde ögrretmen okul içi ve dışında ögrenci çallşmalarm kontrol ediyor süreci takip ediyor. Bu ürünleri sinufta 
sunmasın sağlzyor, değerlendiriyor. Okul diş saatlerde de ögretmenin ölçme ve değgerlendirme ile okulla ve eğitimle ilgili islerde vakit ayırmasına neden oluyor. Bir yą̧ı sınav kâğ̆tlarm ögretmen 2 saat içinde okuyabilirken bu günlerini alabiliyor. Artı bunun e-okul sistemine işlenmesi gerekiyor, tarib-süresinde. Bu tarib-sürede sinfta sunulmasi, sisteme girilmesi bu ayr bir külfet getiriyor...” (Ö2, s. 8). Katılımcıların çoğunluğu alternatif ölçme ve değerlendirmenin geleneksel ölçme ve değerlendirmeye göre maddi giderinin fazla olduğunu düşünmektedir. Görüşülen dokuz öğretmenin altıs1 öğrenciye ve dolayısıyla veliye, iki öğretmen ise öğretmene maddi bir külfet getirdiğini düşünmektedir. Ö1 ve Ö2 veliye maddi külfet getirdiğini düşünen öğretmenlerdendir. Ancak Ö1 bu dezavantajın bazı veliler tarafından evdeki atık malzemelerin kullanılması neticesinde avantaja çevrildiğini iddia etmektedir. Ö1 bu düşüncesini şu şekilde ifade etmiştir: “...A.Ale kendine bir yüke getirdiğini düsünüyor ama bence çok güz̧el oldu. Yani evet parasal, işte projeler performanslar bir de sürekli uğraşmak zorunda olduğu için kirtasiye masrafi. Ama bunu beceren aile projesini evdeki atık malzemelerden de yapabiliyor...” (Ö1, s. 7). Ö2 ise öğrencilerin evdeki malzemeleri bu tür çalışmalarda kullansa bile yine de dışarıdan para vererek malzeme alınması gerektiğini düşünmektedir.

Katılımcıların çoğunluğu alternatif ölçme değerlendirmede objektif olamadıklarını düşünmekte ve bu durumu açıkça ifade etmektedirler. Öğretmenlerin bunu açıç̧a söylemeleri bu durumun farkında olduklarını ancak buna bir çözüm bulamadıklarını göstermektedir. Genel olarak öğretmenler öğrencilerin çalışmalarını değerlendirirken öğrencilerin sınıf içindeki durumlarından ve yapılan çalışmaların güzelliğinden etkilendiklerini dile getirmektedirler. Ö1 bu teknikleri kullanırken duygusal davrandığını ve öğrencilerin sınıf içi performanslarının ve dersteki başarılanının etkisi altında kaldığını düşünmektedir. Ö1 bu düşüncelerini şu cümlelerle ifade etmiștir:

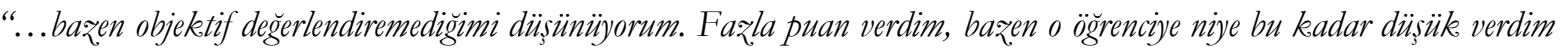
diye düş̈̈üyorum. Onu bir türlü tam böyle, duygusal davranyorum mesela çok iyi bir ögrencim çok güzel bir proje getirmemiş. Ama çok iyi bir ögrenci, süper, kıyıp ta ona düsü̈k not veremiyorum. Yani bir şeyler yapmıs çabalamıs diyorum. Bir de sinıfta çok iyi bir ögrenci. Aslında yapmam gerekirdi diye dïşünüyorum. Bu onun göreviydi, ondan beklediğim gibi yapmamıs diyorum. Ama gene keyamiyorum yani..." (Ö1, s. 13).

Ö8 ise verdiği çalışmanın öğrenci tarafından yapılmamış olduğunu anlasa bile değerlendirme yaparken çalışmanın güzelliğinden etkilendiğini ifade etmektedir. Ö8 bu düşüncesini şöyle ifade etmiştir: “...Proje değerlendirmesi yaparken çocuğun kendi elinden çıkmış olan çalışmayı anlayabiliyorsun. Bir de velininkini görüyorsun. Velinin yaptı̆̆ da güzel oluyor. Kendi kendine ya buda çok güzel olmuş diyorsun. Değerlendirmeyi çok objektif yapamiyorsun. Orda bunun etkisinde kaliyorsun..." (Ö8, s. 4).

Katılımcıların çoğunluğu proje, performans vb. çalışmalarda velilerin öğrencilere yardım ettiğini düşünmektedir. Ö2, velilerin bir noktaya kadar öğrencilere yardım edebileceği görüşündedir. Ö2 bu düşüncesini şu şekilde ifade etmiştir: “...Veli desteği bir yere kadar hos karşılanabiliyor. Ancak bą̧lar çocuğunu başarısız olarak görüyor ve çalısmayı yapamayacağım düsünerek, güvenmediği ve düsük not almaması için çalışmayı kendisi yapan velilerde var. Hatta dısarıda parayla yaptımp ödevini gönderen velilerde oluyor...” (Ö2, s. 8-9).

Araştırmanın dördüncü sorusu, Sınıf öğretmenlerinin alternatif ölçme ve değerlendirmede karşılaştıkları problemler, sebepleri ve çözümlerine ilişkin görüşlerini belirlemeye yöneliktir. Bu soruya cevap verebilmek amacıyla yapılan analizlerin sonucu Tablo $5 \mathrm{a}, 5 \mathrm{~b}$ ve $5 \mathrm{c}$ 'de verilmiştir. 
Tablo 5a. Sınıf öğretmenlerinin alternatif ölçme ve değerlendirmede karşılaştıkları problemlere ilişkin görüşleri

\begin{tabular}{|c|c|c|c|c|c|c|c|c|c|c|c|c|}
\hline Kategori & Alt Kategoriler & Kodlar & Ö1 & Ö2 & Ö3 & Ö4 & Ö5 & Ö6 & Ö7 & Ö8 & Ö9 & $\mathrm{f}$ \\
\hline & Hazirlarken & Seviyeye ayarlama & + & + & + & + & + & + & + & & & 7 \\
\hline & & Kaynak bulamama & + & & & & + & & & & & 2 \\
\hline & & Ölçütleri belirlemede & & & & & + & & & & + & 2 \\
\hline & & Yerel(çevre) şartlara uyarlama & & + & & + & & & & & & 2 \\
\hline & & Çeşitlendirme & + & & + & & & & & & & 2 \\
\hline & & $\begin{array}{l}\text { Sosyo-ekonomik duruma } \\
\text { uyarlama }\end{array}$ & & & + & + & & & & & & 2 \\
\hline & & Hazır formları uyarlama & & & & + & & & & + & & 2 \\
\hline & & $\begin{array}{lll}\text { Kazanım } & \text { ile } & \text { tekniği } \\
\text { bağdaştırma } & \end{array}$ & + & + & & & & & & & & 2 \\
\hline & & $\begin{array}{l}\text { Uygulamanın çok zaman } \\
\text { alması }\end{array}$ & + & + & + & + & + & + & & + & + & 8 \\
\hline \multirow{9}{*}{ Problemler } & Uygularken & & & & & & & & & & & \\
\hline & & Formların basımı ve dağitımı & + & + & + & + & + & & & + & & 6 \\
\hline & & Herkese sunum yaptıramama & + & + & + & & + & & & + & + & 6 \\
\hline & & Velilerin hazırlaması & & + & + & + & + & & & + & + & 6 \\
\hline & & $\begin{array}{l}\text { Değerlendirmenin } \\
\text { zaman alması }\end{array}$ & + & + & + & + & + & + & & + & + & 8 \\
\hline & Degermenamrirken & Zamaninda getirmeme & + & + & + & & + & + & & + & & 6 \\
\hline & & Çalışmaların saklanması & & + & + & & + & + & & + & + & 6 \\
\hline & & Objektif olamama & + & + & & + & + & + & & + & & 6 \\
\hline & & $\begin{array}{l}\text { Öğretmen } \\
\text { tartışmas1(maddi) }\end{array}$ & & + & & & & & & & & 1 \\
\hline Toplam & & & 10 & 12 & 10 & 9 & 11 & 6 & 1 & 9 & 6 & 74 \\
\hline
\end{tabular}

Katılımcıların karşılaştığ1 problemler hakkındaki görüşleri incelendiğinde, öğretmenlerin bu teknikleri hazırlarken daha çok problemle yüz yüze kaldıkları gibi bir sonuca ulaşılabilir. Ancak öğretmenlerin alternatif ölçme ve değerlendirme tekniklerini hazırlarken karşılaştıkları problemlere bakıldığında öğretmenlerin daha çok bireysel problemlerinden bahsettikleri görülmektedir. Çünkü genel olarak öğretmenlerin bahsettiği problemler ikişer öğretmen tarafından dile getirilmiştir. Sadece öğretmenler bu teknikleri öğrenci seviyesine ayarlamada problem çekiyorum görüşünü genel olarak benimsemişlerdir (7/9).

Katılımcıların geneli alternatif ölçme ve değerlendirme yöntem ve tekniklerini hazırlarken öğrencilerin seviyesine ayarlamada problem çektiklerini ifade etmişlerdir. Öğretmenler genel olarak, yaptıkları çalışmaların öğrenci seviyesine uygun olmasına dikkat ettiklerini ve bunda zorlandıklarını ve çok zaman harcadıklarını düşünmektedirler. Ö1, öğrencilerin zihinlerini harekete geçirecek çalışmaları hazırlamada zorlandığını dile getirmektedir. Ö1’in düşünceleri şöyledir: “...Biraz kendilerini yorsunlar istiyorum. Basit bir şey olmasın, hemen öyle ahp koymasınlar. Onlar hažrlarken zorlanyorum...” (Ö1, s. 8). Ö4 ise ileri ve geri seviyedeki öğrencilerin çalışmaları yapma becerilerinin farklı olması nedeniyle seviye gruplarına yönelik çalışmalar yapılması gerektiğinden bahsetmiştir. Ö4’ün düşünceleri şöyledir: “...Seviye gruplarmm her birine ayrn bir alternatif yöntem kullanman laz̨m. Çünkü senin kullandiğn alternatif tekniği, algisı yükesek çocuk çok rahat yapabilirken diğeri bunda zorlanabiliyor..." (Ö4, s. 8).

Katılımcılar alternatif ölçme ve değerlendirme çalışmalarını uygularken ve değerlendirirken karşılaştıkları en genel problemlerden olan uygulama ve değerlendirmelerin çok zaman almasina bu değerlendirmenin dezavantajlarına değinirken de bahsetmişlerdir. Yine öğretmenlerin çoğunlukla yaşadığı problemlerden olan velilerin çalışmaları hazırlaması ve değerlendirmede objektif olamamaya da öğretmenler dezavantajlarda yer vermişlerdir. Katılımcıların alternatif ölçme ve değerlendirme çalışmalarını uygularken çoğunlukla karşılaştıkları 
diğer problemler formların basımı ve dağıtımı ile herkese sunum yaptıramamadır. Öğretmenler öğrencilerin hazırladığı çalışmaları diğer arkadaşlarına sunmalarına önem vermektedirler. Ancak sınıf mevcutlarının kalabalık olması ve sunumların çok zaman alması gibi çeşitli nedenlerle bunu tam olarak uygulayamadıklarını düşünmektedirler. Ö2 bu duruma çare olarak grup sunumları yaptırdığını ancak bu sınıf mevcuduyla çok fazla grup oluştuğunu ve onlarında tamamına sunum yaptırmanın zor olduğunu ifade etmektedir. Ö2'nin görüşleri şöyledir:

“...Bunun haricinde ögrenci ödevini yapzyor, hazırlyyor. Bunun sunumu var ögrenci ödevini sinfta sunma zorunda... Bunun sunumunda ayr bir sıkentı yaşanyor. Sunumda ne kadar süre ayıracaksinı, sinf mevcudum benim 45 kişiydi. 45 ögrencinin sunum yaptı̆ğm düs̆̈̈nün, sıkıntı. Grup grup yaptı̆̆gnz zaman nerden baksanız 8-9 grup oluyor. Her grubu dinlemeniz gerekiyor. O da oldukeşa fą̧la ders saatini alyor. Ve her ders için bunu yapmak zorundasımı..." (Ö2, s. 9-10).

Katılımcılar çoğunlukla, verdikleri çalışmaların öğrenciler tarafından süresinde teslim edilmediğini düşünmektedirler. Öğretmenler; öğrencilerin çalışmayı evde unutması, çocuğun o gün rahatsızlanması, ailesinin gerekli malzemeyi almaması gibi çeşitli nedenlerden dolayı öğrencilerin belirtilen zaman diliminde çalışmayı teslim etmediklerini dile getirmektedirler. Ö1 de bu konuda ailenin büyük payı olduğunu düşünmektedir. Ö1’in görüşleri şöyledir: “...Projeler zamanında teslim edilmiyor. Bazen o sıkıntılar yaşıyorum. 0 da aileden kaynaklanıyor. Cocuk diyor ögretmenim annem bala şunu almad, bunu almad. Isste şunu yapamadim. Kurtasiye malzemesine ibtiyaç olduğu için onlar tam zamaninda yerine gelmiyor...” (Ö1, s. 10).

Katılımcıların çoğunluğu, alternatif ölçme ve değerlendirmede öğrencilerin yapmış olduğu birçok çalışmanın ve öğretmenlerin bunları değerlendirmede kullandığı birçok dokümanın oluştuğunu dile getirmektedir. Ayrıca öğretmenler bunların muhafaza edilmesinin oldukça sıkıntılı olduğunu ve sınıflarında koyacak yer kalmadığı için öğrencilerin evlerine gönderdiklerini ifade etmektedirler.

Tablo 5b. Sınıf öğretmenlerinin alternatif ölçme ve değerlendirmede karşılaștıkları problemlerin sebeplerine ilișkin görüşleri

\begin{tabular}{|c|c|c|c|c|c|c|c|c|c|c|}
\hline Kategori & Kodlar & Ö1 & Ö2 & Ö3 & $\ddot{\mathrm{O}} 4$ & Ö5 & Ö6 Ö7 & Ö8 & Ö9 & $\mathrm{f}$ \\
\hline & Sınıfların kalabalıklığı & + & + & + & + & + & + & + & + & 8 \\
\hline & Programın yoğunluğu & + & + & + & + & + & & + & & 6 \\
\hline & Öğretmenlerin yetersizliği & & & + & + & + & & + & + & 5 \\
\hline & Araç-gereç eksikliği & + & & + & & + & & + & & 4 \\
\hline & Bina yetersizliği & & + & + & + & & & & + & 4 \\
\hline \multirow[t]{3}{*}{ Sebepleri } & B1kkınlık yapmas1 & & & + & & & & + & + & 3 \\
\hline & Velinin bilgi eksikliği & & + & + & & & & & & 2 \\
\hline & Faydasına olan inanç & & & & + & & + & & & 2 \\
\hline Toplam & & 3 & 4 & 7 & 5 & 4 & 2 & 5 & 4 & 34 \\
\hline
\end{tabular}

Katılımcıların karşılaştıkları problemlerin sebepleri hakkındaki görüşleri incelendiğinde, genel olarak öğretmenler karşılaştıkları problemlerin sebebi olarak eğitim sistemini ve sunduğu olanakları görmektedirler. Yukarıda verilen sekiz sebepten sadece iki tanesi öğretmenlerin kendisiyle ilgilidir. Öğretmenlerin geneli bu değerlendirmede karşılaştıkları problemlerin sebebini sınıf mevcutlarının kalabalık olmasına bağlamaktadır. Ayrıca öğretmenlerin çoğunluğu da program yoğunluğu ve öğretmenlerin alternatif ölçme ve değerlendirme hakkındaki yetersizliklerinin bu sorunlara sebep olduğunu düşünmektedir. Öğretmenler, bu yöntem ve teknikleri kalabalık sınıflarda uygularken çok zorlandıklarını, isteyen bütün öğrencilerine çalışmalarını sunma imkânı veremediklerinden dolayı da öğrencilerin üzüldüğünü ve morallerinin bozulduğunu ifade etmektedirler. Bu şekilde düşünen Ö1’in görüşleri şu şekildedir: “...kalabalık simflarda uygulanamıyor. Uygulanyyor ama çok zor. Öğrencileri küstürebiliyoru: 34 ögrencinin 34'ünü birden okutmam mümkün değgil. Öğrenci mesela ben yaptım ögretmen okutmadı beni. Bir daha ki çalışmada yapmayacağım. Öbür sefer yazmıștım ne kadar güzeldi. Isste öğretmen önemsemedi diyebiliyor..."(Ö1, s. 6). 
Programın yoğun olmasından şikâyetçi olan öğretmenler, yılsonuna programdaki konuları yetiştirmeye çalıştıklarını ve bundan dolayı da uygulaması ve değerlendirmesi çok uzun zaman alan alternatif ölçme ve değerlendirme çalışmalarına yeterince zaman ayıramadıklarını ifade etmektedirler. Bu şekilde düşünen Ö2 düşüncelerini şu cümlelerle ifade etmektedir:

“...Programdaki konu yükeü oldukça fąla. Zaten müfredat kapsammda konularm yetiştirilmesi süre olarak biz̨i

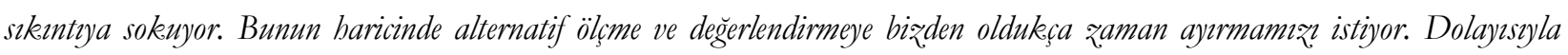
yullke plan içerisine bir ölçme değerlendirme zamam koyulmah. Uzun bir süre ayıryoruz birde müfredatın oldukça sıkısmasına neden oluyor. Ögrretmeni- ögrenciyi sıkıntrya sokmaktadir. Bu noktada sorun sadece öğretmenin isteyip istememesi değgl

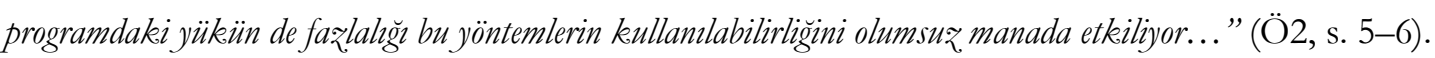

Katılımcıların çoğunluğu öğretmenlerin alternatif ölçme ve değerlendirmede yetersiz olduğunu düşünmekte ve bunun nedeni olarak da öğretmenlerin konu hakkında bilgi eksikliği içinde oluşunu görmektedirler. Ö4 öğretmenlerin bu yöntem ve teknikleri nasıl kullanacağını ve elde ettiği sonuçları nasıl değerlendireceklerini bilmediklerini düşünmektedir. Ö4 bu görüşlerini şöyle ifade etmiştir:

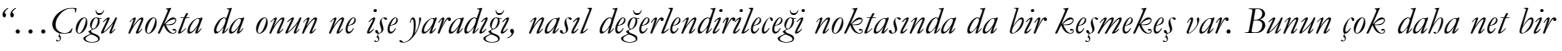

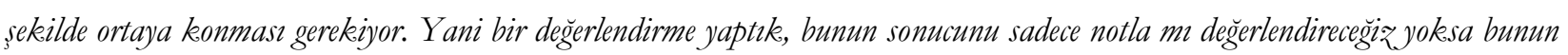

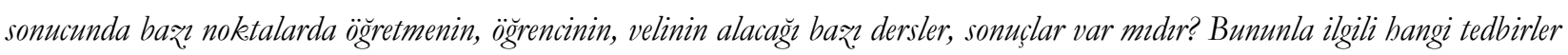
alınmalıdır? Buna uygunda bir çalıșma- bilgilendirme yapılması gerektiğini düşünüyorum...” (Ö4, s. 7).

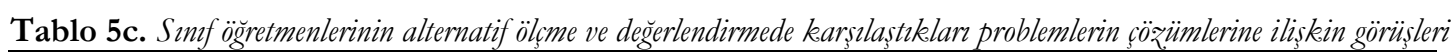

\begin{tabular}{|c|c|c|c|c|c|c|c|c|c|}
\hline Kategori & Kodlar & Ö1 & Ö2 & Ö3 & Ö4 & Ö5 & Ö6 Ö7 & Ö8 & Ö9 \\
\hline & Mevcutların azaltılmas 1 & + & + & + & + & + & & + & + \\
\hline & Araç-gereç eksikliği giderilmeli & + & & + & + & + & + & + & + \\
\hline & Öğretmene konu ile ilgili eğitim verilmeli & + & + & + & + & + & + & & + \\
\hline & Altyapının tam olması & + & + & & + & & + & & + \\
\hline & Elektronik uygulama & & + & & + & + & + & + & \\
\hline & Ücretsiz çoğaltma imkânı olmalı & & + & + & & + & + & & \\
\hline & Öğrencilere seçme şansı verilmeli & + & & + & + & & + & & \\
\hline & Tekniklerin yer aldığı kitapçık olmalı & + & & + & & & + & & \\
\hline & Programda ölçmeye yer ayrilmalı & & + & + & + & & & & \\
\hline & $\begin{array}{l}\text { Yeniliklerde öğretmenlerin görüşleri } \\
\text { alınmalı }\end{array}$ & & & + & + & & + & & \\
\hline $\begin{array}{l}\text { Çözüm } \\
\text { Önerileri }\end{array}$ & $\begin{array}{l}\text { Uzman bir kurul performans ve projeleri } \\
\text { belirlemeli }\end{array}$ & + & & + & + & & & & \\
\hline & Yeni bina yapımı & & + & & & & & & + \\
\hline & Sınav sisteminin değiştirilmesi & & & + & + & & & & \\
\hline & Her derste verilmemeli & & & + & & & & & + \\
\hline & Depo & & + & & & & & & \\
\hline & Çalışma odası & + & & & & & & & \\
\hline
\end{tabular}

Toplam

$\begin{array}{lllllllll}8 & 8 & 11 & 10 & 5 & 8 & 0 & 3 & 7\end{array}$

60

Katılımcıların karşılaştıkları problemler hakkındaki çözüm önerileri incelendiğinde, öğretmenlerin karşılaştıkları problemlerin sebepleri ile paralel görüş bildirdikleri görülmektedir. Öğretmenlerin, karşılaştığ1 problemlerin sebepleri içinde en çok vurguladıkları neden sınıf mevcutlarının kalabalık olmasıydı. Öğretmenler bu soruna basit bir çözüm sunmuşlar ve sınıf mevcutlarının azaltılması gerektiğini dile getirmişlerdir. Genel olarak öğretmenler alternatif ölçme ve değerlendirmenin tam olarak uygulanabilmesi için sınıf mevcutlarının yirmi öğrenci civarında olması gerektiğini dile getirmişlerdir. Öğretmenlere göre sınıf mevcutları yirmi 
civarında olursa bütün öğrencilere çalışmalarını sunma imkânı verilebilir ve her öğrenciyle bire bir ilgilenme ihtimali doğar. Bu şekilde düşünen Ö4'ün görüşleri şöyledir: “...Bu teknikler sinf mevcudunun 20-25 arasında olduğu simeflarda uygulanabilir. Ö̆gretmenin simı 60-70 kişi olursa sürecin değerlendirilmesi birebir çalıs̆malar yapılması, doğgru ölçme yapılması ve ögrencilere bunun bildirilmesi oldukça zaman alan bir şey...” (Ö4, s. 8).

Katılımcıların geneli alternatif ölçme ve değerlendirmenin etkin biçimde uygulanabilmesi için araç-gereç eksikliğinin giderilmesi gerektiğini düşünmektedir. Ö1, Ö8 ve Ö9 da gerekli olan araç gerecin bakanlık tarafından karşılanması ve çalışmaların sınıf içinde yapılması gerektiğini ifade etmişlerdir. Ö8 bunun gerçekleşmesi halinde çalışmaların öğrenci haricinde yapılmasının engelleneceğini düşünmektedir. Ö8’in görüşleri şöyledir: “...Malz̧emeler okulda bulunabilir. Hiç eve göndermeden okulda bunlar yapulabilmeli. Veli katkısım azaltmamı lazım. Veli çocuğa duygusal anlamda destek olmah. Cocuklarn davranışlarm geliştirici biçimde destek olmal. Yani keşlke bizlle beraber simfta yapulabilse hepsi...” (Ö8, s. 6).

Katılımcıların geneli öğretmenlere alternatif ölçme ve değerlendirme ile ilgili eğitim verilmesi gerektiğini ve bunun da hizmet içi eğitim faaliyeti şeklinde gerçekleştirilebileceğini düşünmektedirler.

\section{TARTIŞMA ve SONUÇ}

Araştırmadan elde edilen sonuçlar öğretmenlerin alternatif ölçme ve değerlendirme ile ilgili ortak bir algısının olmadığını ve öğretmenlerin bu kavram ile ilgili kavram karmaşası yaşadıklarını göstermektedir. Bu sonuç beklenen bir durum değildir. Çünkü 2005 yllından itibaren yürürlükte olan ilköğretim programının ön gördüğü alternatif ölçme ve değerlendirme kavramı ile ilgili olarak öğretmenlerin ortak bir alg1 geliştirmeleri beklenmektedir. Ancak yapılan araştırmalar da bu bulguya destek olacak yöndedir. Mamur (2009) araştırmasında öğretmenlerin uyguladı̆̆1 alternatif ölçme ve değerlendirme tekniklerinin öğretmenden öğretmene değiştiğini ve sistemli bir biçimde uygulanamadığını tespit etmiştir. Lentz de (1997) öğretmenlerin alternatif ölçme ve değerlendirmede fikir ayrılıklarının bulunduğunu belirlemiştir. Ayrıca Akata (2007) ve Arda (2009) yaptıkları araştırmalarda alternatif ölçme ve değerlendirmeyi öğretmenlerin karışık bulduklarını belirlemiştir.

Araştırma sonuçlarına göre katılımcılar; alternatif ölçme ve değerlendirmenin öğrencilerin öz güvenini artırdığını, kendilerini tanımalarını sağladığını ve arkadaşları ile kendilerini objektif olarak değerlendirebilmelerini sağladıklarını düşünmektedirler. Sınıf öğretmenleri bu değerlendirmenin öğrencileri daha iyi tanımalarını ve yeteneklerinin farkına varmalarını sağladığını ayrıca öğrencilerin motivasyonunu arttırdığını düşünmektedirler. Diğer araştırmalardan elde edilen sonuçlar da bu bulguları doğrular yöndedir. Zimbicki (2007) yaptığı araştırmada alternatif ölçme ve değerlendirmenin öğrencilerin öz yeterlik algılarını ve motivasyonlarını artırdığını bulmuştur. King, Schroeder ve Chawszczewski (2001) yaptıkları araştırmada, otantik görevlerin verildiği özel eğitim öğrencilerinin performanslarının otantik görev verilmeyenlere göre daha çok arttığını bulmuşlardır. Engel, Pulley ve Rybinski’nin (2003) yaptıkları araştırmada bu değerlendirmenin öğrencilerin öz güvenini arttırdığını ve bireysel öğrenmelerini geliştirdiğini bulmuşlardır. Larson da (2005) portfolyo toplama sürecinin öğrencilerin daha detaylı olarak performanslarının izlenmesini sağladığını tespit etmiştir. Ataman da (2007) alternatif ölçme ve değerlendirme ile öğrencilerin derse ilgilerinin ve başarılarının arttığını, öğrencilerin kendilerini daha iyi ifade edebildiklerini ve öğretmenlerin öğrencileri her yönüyle değerlendirebildiklerini tespit etmiştir. Mamur da (2009) portfolyonun öğrencilerin kendilerini tanımalarını sağladığını, öğrenme sürecini desteklediğini ve kapsamlı ve derinlemesine değerlendirme imkânı sağladığını bulmuştur.

Araştırma sonuçlarına göre katılımcılar, alternatif ölçme ve değerlendirmenin en önemli avantajının farklı zekâ türlerine hitap etmesi ve öğrencilerin bu çalışmaları sevmesi olduğunu düşünmektedirler. Yapılan diğer araştırmalarda da bu sonuca destek olacak yönde sonuçlar elde edilmiştir. Mamur (2009) yaptı̆̆ araştırmada öğrencilerin portfolyoya yönelik tutumlarının olumlu olduğunu ve portfolyoların içinde farklı türde performans gerektiren çalışmalar bulunması gerektiğini belirlemiştir. Cansız Aktaş (2008) ve Orhan da (2007) yaptığı araştırmalarda öğretmenlerin, alternatif ölçme ve değerlendirmenin çok yönlü değerlendirme imkânı sunduğunu düşündüklerini belirlemişlerdir. Koh ve Luke (2009) yaptıkları araştırmada öğretmenlerin öğrencilerine verdiği otantik görevlerin onların öğrenme ve performanslarını olumlu yönde etkilediğini 
belirlemişlerdir. Engel, Pulley ve Rybinski (2003), alternatif ölçme ve değerlendirme odaklı etkinlik kullanımının öğrencilerin konuları hatırda tutmalarına yardımcı olduğunu ve onların bireysel öğrenmelerini geliştirdiğini tespit etmişlerdir. Bell ve Bell (2003) çoklu zekâ teorisi ile sınıftaki öğretimin birleştirilmesinin öğrencilerin öğrenme performanslarını arttıracağını düşünmektedirler. Bunun gerçekleşmesi için de portfolyoların, projelerin, kompozisyonların kullanılması gerektiğini ifade etmektedirler.

Araştırma sonuçlarına göre öğretmenlerin alternatif ölçme ve değerlendirmede karşılaştıkları problemler; teknikleri öğrenci seviyesine ayarlama, uygulamanın çok zaman alması, formların basımı dağıtımı, bütün öğrencilere sunum yaptıramama, velilerin çalışmaları yapması, değerlendirmenin çok zaman alması, çalışmaların zamanında teslim edilmemesi, öğrenciler tarafından yapılan çalışmaların saklanması ve öğretmenlerin çalışmaları değerlendirirken objektif olamamasıdır. Yapılan diğer araştırmalarda da benzer sonuçlar elde edilmiştir. Craig ve Mccormig (2002) araştırmalarında, alternatif ölçme ve değerlendirme uygulamaları yapılan sınıflarda öğretmenlerin değerlendirme için sınıflardaki çalışma ve planlamaya büyük zaman harcadıklarını belirlemişlerdir. Mamur (2009), portfolyo değerlendirme sürecinde yaşanan güçlüklerin; öğretmenlerin geleneksel ölçme ve değerlendirmeye göre daha fazla zaman ayırmak zorunda kalmas1, objektif olmaması, materyal ve ortam kullanımına dair güçlükler ve öğrenci seviyelerinin farklılı̆̆ olduğunu belirlemiştir. Bal'ın (2009) yaptığı araştırmaya göre öğretmenlerin karşılaştığı sorunlar; çalışmaların veliler tarafından yapılması, ödevlerin internetten olduğu gibi alınması, öğrencilerin görevleri zamanında getirmemesi, çalışmalar için zaman yetersizliği, öğretmenlerin bilgi eksikliği, karışık olması, okulun fiziki şartlarının yetersiz olmas1, öğrencilere sunum yaptıramama şeklinde özetlenebilir. Orhan'ın (2007) yaptı̆̆ araştırmada öğretmenlerin karşılaştığı en sık problemin kırtasiye işlerinin ve değerlendirmenin çok zaman alması olduğu tespit edilmiştir. Birgin de (2010) öğretmenlerin yaşadığı sıkıntıları; zaman yetersizliği, öğretmenlerin alternatif ölçme ve değerlendirmede bilgi eksikliği içinde olması, çalışmaların puanlanması ve saklanması ve çalışmaların öğrenci haricinde yapılması şeklinde özetlemiştir.

Araştırma sonuçlarına göre katılımcılar, alternatif ölçme ve değerlendirmede yaşanılan problemlerin sebepleri olarak sınıfların kalabalık olmasını, programın yoğunluğunu ve öğretmenlerin yetersizliğini görmektedirler. Yapılan diğer araştırmalarda da benzer sonuçlar elde edilmiştir. Bell ve Bell (2003) yaptıkları araştırmada, öğrenci başarısının arttırılması için alternatif ölçme ve değerlendirmelerin uygulandığı çözüm stratejilerinden bazılarının zaman sınırlaması, sınıf büyüklüğü ve öğrencilerin farklı tecrübe düzeyleri nedeniyle başarısız olduğunu tespit etmişlerdir. Watt (2005) araştırmasında, alternatif ölçme ve değerlendirme tekniklerinin kullanılmama nedenlerinin zaman yetersizliği ve öğretmenlerin planlama yapamamalarından kaynaklandığını tespit etmiştir. Birgin (2010) yaptığı araştırmada öz ve akran değerlendirmenin çok sık kullanılmamasının nedenleri olarak; öğretmenlerin bilgi eksikliği, zaman yetersizliği ve öğrenci sayısının ve değerlendirme formlarının fazla olması olduğunu tespit etmiştir. Cansız Aktaş (2008) ve Orhan (2007) kalabalık sınıfların, öğretmenlerin bu teknikleri tam olarak uygulamalarını engellediğini tespit etmişlerdir. Ünsal da (2013) araç-gereç eksikliğinden, tekniklerin çok zaman alması ve öğretmenlerin bazı teknikleri bilmemesinden dolayı alternatif ölçme ve değerlendirme tekniklerinin uygulanamadığını belirlemiştir.

Araştırma sonuçlarına göre katılımcıların karşılaştıkları problemlere ilişkin çözüm önerileri şunlardır; sınıf mevcutları azaltılmalı, araç-gereç eksikliği giderilmeli ve öğretmenlere alternatif ölçme ve değerlendirme ile ilgili eğitim verilmelidir. Burada dikkati çeken nokta; öğretmenlerin alternatif ölçme ve değerlendirmede karşılaştıkları problemler, sebepleri ve bunlara yönelik getirdikleri çözüm önerilerinin birbirine paralel ve tutarlı olmasıdır. Örneğin karşılaşılan problemlerden bir tanesi tekniklerin uygulanmasının çok zaman almasıdır. Bu problemin sebebi ise sınıf mevcutlarının kalabalıklığı, öğretmenlerin yetersizliğidir. Öğretmenlerin önerdikleri çözüm ise sınıf mevcutlarının azaltılması ve öğretmenlere alternatif ölçme ve değerlendirme ile ilgili eğitim verilmesidir. $\mathrm{Bu}$ durum öğretmenlerin karşılaştıkları problemlerin ve çözümlerinin farkında olduklarını göstermektedir. Yapılan diğer araştırmalarda da benzer sonuçlar elde edilmiştir. Culbertson ve Wenfan (2003) küçük sınıfların, ilçe destekli eğitimin, plan için yeterli zaman ayırmanın, yapılan uygulamaların, işbirliği ve yansıma yapmanın öğretmenlerin alternatif değerlendirme uygulamalarına ve bilgilerine olumlu katkısının olduğunu göstermiştir. Bal da (2009) yaptığı araştırmada öğretmenlerin karşılaştıkları problemlere getirdikleri 
çözüm önerilerini birlikte değerlendirmiştir. Öğretmenler, zaman yetersizliğine çözüm olarak sınıf mevcutlarının azaltılmasını, öğretmenlerin alternatif ölçme ve değerlendirmedeki bilgi eksikliğine çözüm olarak öğretmenlere uygulamalı eğitimler verilmesini, araç-gereç eksikliğine çözüm olarak da bunların tamamlanmasını önermişlerdir. Birgin de (2010) öğretmenlerin karşılaştıkları problemlere çözüm olarak; öğretmenlere uzman desteği sağlanması, öğretmenlerin bilgi ve yeterlik bakımından daha donanımlı hale getirilmesi ve okulların fiziki alt yapılarının uygun hale getirilmesi gerektiğini öne sürmüştür..

\section{5. ÖNERIILER}

Araştırma sonuçlarına göre şu önerilerde bulunulmuştur:

İl ve İlçe Milli Eğitim Müdürlükleri tarafindan düzenlenecek eğitim faaliyetleri kapsamında öğretmenlere, alternatif ölçme ve değerlendirme kavramı ve alternatif ölçme ve değerlendirmenin geleneksel ölçme ve değerlendirmeye göre avantajları hakkında bilgiler verilmelidir.

Öğretmenler alternatif ölçme ve değerlendirme tekniklerini hazırlarken, uygularken ve değerlendirirken birçok sorun yaşamaktadırlar. Bu sorunların çözümü noktasında okulların fiziksel alt yapıları yeterli hale getirilmeli, sınıf mevcutları azaltılmalı, kullanılan malzemeler ücretsiz sağlanmalı, çalışma odaları olmalı, çalışmaların saklanacağı odalar olmalı, formlar hazır olarak verilmelidir.

Velilerin öğrenciler yerine çalışmaları yaptıkları belirlenmiştir. Bunu önlemek amacıyla okullarda, velilere alternatif ölçme ve değerlendirme çalışmalarının amacını ve öğrencilere faydalarını anlatan seminerler düzenlenmelidir.

\section{KAYNAKÇA}

Akata, A. (2007). Türkşe programyla ilgili ölçme ve değerlendirme sürecinin işlevselliği üzerine bir araștırma (Tekirdăg ili örneği). (Yayınlanmamış yüksek lisans tezi). Abant İzzet Baysal Üniversitesi, Bolu.

Algan, S. (2008). İlkögretim 6 ve 7. simf sosyal bilgiler dersi ögretim programmnn ölçme ve değerlendirme öğesinin ögretmen görüsleri açısından incelenmesi. (Yayınlanmamış yüksek lisans tezi). Çukurova Üniversitesi, Adana.

Arda, D. (2009). İlköğretim sme ögretmenlerinin 2005 ögretim program ekseninde ölçme ve değerlendirme alanndaki yeterlilik ve görüşlerinin incelenmesi. (Yayınlanmamıs yüksek lisans tezi). Marmara Üniversitesi, İstanbul.

Ataman, M. (2007). Benzeșen ve ayrışan yönleriyle 1998 ve 2004 ilk:ögretim sosyal bilgiler öğretim programlarnnda (4-5. simflar) ölcme ve değerlendirme yöntem ve teknikleri ve bunlara ilișkin ögretmen görïsleri. (Yayınlanmamıs yüksek lisans tezi). Marmara Üniversitesi, İstanbul.

Bal, A. P. (2009). İlköğretim beșinci sımf matematik ögrretiminde uygulanan ölçme ve değerlendirme yaklașımlarnmn ögretmen ve öğrenci görüşleri doğrultusunda değerlendirilmesi. (Yayınlanmamış doktora tezi). Çukurova Üniversitesi, Adana.

Bell, A. \& Bell, M. (2003). Devoloping authentic assessment methods form a multiple intelligences perspective. Master of Arts Action Research Project, Saint Xavier University (ERIC Document Reproduction Service No. ED: 479391).

Birgin, O. \& Gürbüz, R. (2008). Sınıf öğretmeni adaylarının ölçme ve değerlendirme konusundaki bilgi düzeylerinin incelenmesi. Selçuk. Üniversitesi Sosyal Bilimler Dergisi, 20, 163-179.

Birgin, O. (2010). 4-5. sinff matematik ögretim programında öngörülen ölçme ve değerlendirme yaklaşımlarmmn ögretmenler tarafindan uygulanabilirliği. (Yayınlanmamış doktora tezi). Karadeniz Teknik Üniversitesi, Trabzon.

Cansız Aktaş, M. (2008). Öğretmenlerin yeni ortaögretim matematik öğretim programının ölçme dĕgerlendirme boyutuna bakışlarmm incelenmesi. (Yayınlanmamış doktora tezi). Karadeniz Teknik Üniversitesi, Trabzon.

Craig, C. L. \& McCormick, E. P. (2002). Improving student learning through authentic assessment. (Unpuplished master theses). Saint Xavier University, Chicago (ERIC Document Reproduction Service No. ED: 468053).

Culbertson, L. D. \& Wenfan, Y. (2003). Alternative assessment: Primary grade literacy teachers' attitudes and practices (ERIC Document Reproduction Service No. ED: 479794).

Çalışkan, İ. (2009). Fen ve teknoloji ögretmen adaylarmm tamamlayzc ölı̣me ve değerlendirme yaklaşımlarm kullanma becerileri ile fen ve teknoloji ögrretmen ve ögretmen adaylarmin bu yaklaşımlarla ilgili görüsleri hakekinda durum belirleme çalısmasi Ankara ili ve Hacettepe üniversitesi örneği. (Yayınlanmamış doktora tezi) Hacettepe Üniversitesi, Ankara.

Engel, M., Pulley, R. \& Rybinski, A. (2003). Authentic assessment: It really Works. Master's Action Project, Saint Xavier University and Skyligt (ERIC Document Reproduction Service No. ED: 479959).

Genç, N. (2008). Beden eğitimi ögretmenlerinin ölçme-değerlendirme uygulamalar ve yeterlik algular. (Yayınlanmamış yüksek lisans tezi). Mersin Üniversitesi, Mersin. 
Gök, B. \& Şahin, A. E. (2009). İlköğretim 4. ve 5. sınıf öğretmenlerinin değerlendirme araçlarını çoklu kullanımı ve yeterlik düzeyleri. Ë̈itim ve Bilim, 34 (153) 127-143.

Güneş, A. (2007). Sinnf öğretmenlerinin kendi algzlarnna göre ölçme ve değerlendirme yeterlikleri. (Yayınlanmamış yüksek lisans tezi). Marmara Üniversitesi, İstanbul.

Karahan, U. (2007). Alternatif ölçme değerlendirme metotlarnndan grid, tamlayuc dallanmış ağas ve kavram haritalarmm biyoloji ögretiminde kullanılması. (Yayınlanmamıș yüksek lisans tezi). Gazi Üniversitesi, Ankara.

Karasar, N. (2005). Bilimsel araştırma yöntemi (15. baskı). Ankara: Nobel Yayın

Kilmen, S., Kösterelioğlu, M. \&Kösterelioğlu İ. (2007). Öğretmen adaylarının ölçme değerlendirme araç ve yaklaşımlarına ilişkin yeterlik algıları. AIB̈Ü, Eğitim Fakültesi Dergisi, 7 (1), 129-140

King, M. B, Schroeder, J. \& Chawszczewski, D. (2001). Authentic assessment and student performance in inclusive schools (ERIC Document Reproduction Service No. ED: 467479).

Koh, K. \& Luke, A. (2009). Authentic and conventional assessment in Singapore schools: An empirical study of teasher assignments and student work. Assessment in Education. Principles, Policy \& Practice, 16 (3), 291318.

Larson, A. M. (2005). Traditional and authentic assessments in mathematics instruction with first-grade students: Three case studies. University of South Dakota. ProQuest Dissertations and Theses, , 88-88 p. Alinan yer http://search.proquest.com/docview/305386015?accountid=12251. (305386015).

Mamur, N. (2009). Anadolu güzel sanatlar lisesi resim bölümü ögrencilerinin sanatsal yeterliliğini ölgme ve değerlendirmede eğitsel gelisim dosyasının (portfolyo) rolü. (Yayınlanmamış doktora tezi). Gazi Üniversitesi, Ankara.

Maral, D. Y. (2009). Sinf ögretmenlerinin ölçme değerlendirme yeterlik düzeyleri ve bižmet içi eğitim gereksinimleri. (Yayınlanmamıs yüksek lisans tezi). Çanakkale Onsekiz Mart Üniversitesi, Çanakkale.

McMillan, J. H. (2007). Classroom assessment: principles and practice for effective standart-based instruction (Fourth edition). Boston: Pearson Education.

MEB (2005). İlköğretim okulu ders programları ve öğretim kılavuzları. Erzurum: Yakutiye Yayıncılık

MEB (2012). İlköğretim kurumları yönetmeliği. Alınan yer http://mevzuat.meb.gov.tr/html/225_0.html

Miles, M. B. \& Huberman, A. M. (1994). Qualitative data analysis: An expanded source book (second edition). Thousand Oaks: Sage Puplications.

Neuman Lentz, D. L. (1997). The assessment, grading and reporting practices of selected elementary school teachers and principals. The University of Texas at Austin). ProQuest Dissertations and Theses, , 524-524 p. Alinan yer http://search.proquest.com/docview/304375083? accountid=12251. (304375083).

Okur, M. (2008). 4. ve 5. sinf ögretmenlerinin fen ve teknoloji dersinde kullanulan alternatif ölçme ve değerlendirme tekniklerine ilişkin görüslerinin belirlenmesi. (Yayınlanmamış yüksek lisans tezi). Zonguldak Karaelmas Üniversitesi, Zonguldak.

Orhan, A. T. (2007). Fen eğitiminde alternatif ölome ve değgrlendirme yöntemlerinin ilkö̈gretim ögretmen adayz, ögretmen ve ögrenci boyutu dikekate alnarak incelenmesi. (Yayınlanmamıs doktora tezi). Gazi Üniversitesi, Ankara.

Pınarbaşı, D. (2007). 4. ve 5. simflarda eski ve yeni ögrretim programma göre okutulan sosyal bilgiler ders kitaplarndaki

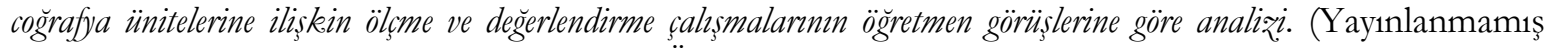
yüksek lisans tezi). Çanakkale Onsekiz Mart Üniversitesi, Çanakkale.

Tabak, R. (2007). İlkögretim 5. smif fen ve teknoloji ders programını ögrenme -ögretme ve ölcme değerlendirme yaklasımlar kapsaminda incelenmesi (Muğla ili örneği). (Yayınlanmamış yüksek lisans tezi). Muğla Üniversitesi, Muğla.

Torçuk, F. Ç. (2008). 2006-2007 eğitim ögretim ynl ilkögrretim 6. sinf matematik dersi ögrretim programmnn "ölçme ve değerlendirme” boyutunun uygulanma düreyinin incelenmesi (Muğga ili örneği). (Yayınlanmamış yüksek lisans tezi). Muğla Üniversitesi, Muğla

Uysal, K. (2008). Öğrencilerin ölçme değerlendirme sürecine katılması: akran dĕgerlendirme ve öz değerlendirme. (Yayınlanmamıs yüksek lisans tezi). Abant İzzet Baysal Üniversitesi, Bolu.

Ural, A. \& Kılıç, İ. (2006). Bilimsel Araştırma Süreci ve SPSS ile Veri Analið̧. Ankara: Detay Yayıncılık.

Ünsal, H. (2013). Yeni öğretim programlarının uygulanmasına ilişkin sınıf öğretmenlerinin görüşleri. İlkögrretim Online, 12(3), 635-658. Alınana yer http://ilkogretim-online.org.tr/upcoming.html.

Watt, H. M. G. (2005). Attitudes to the use of alternative assessment methods in mathematics: A study with secondary mathematics teachers in Sydney, Australia. Educational Studies in Mathematics, 58, 21-44

Yıldırım, A. \& Şimşek, H. (2011). Sosyal bilimlerde nitel araştırma yöntemleri (8. baskı). Ankara: Seçkin Yayıncılık.

Zimbicki, D. (2007). Examining the effects of alternative assessment on student motivation and self-efficacy. Walden University). ProQuest Dissertations and Theses, 276-276 p. Alinan yer http://search.proquest.com/docview/304761711 ?accountid=12251. (304761711).

\section{Citation Information}

Özenç, M., Doğan, C. \& Çakır, M. (2017). Sınıf Öğretmenlerinin Alternatif Ölçme ve Değerlendirme Hakkındaki Görüşlerinin Belirlenmesi. Dicle Üniversitesi Zija Gökalp Eğitim Fakültesi Dergisi, 30, 588-608. 